\title{
Measurement and modelling of tropospheric reactive halogen species over the tropical Atlantic Ocean
}

\author{
A. S. Mahajan ${ }^{1}$, J. M. C. Plane ${ }^{1}$, H. Oetjen ${ }^{1}$, L. Mendes ${ }^{2}$, R. W. Saunders ${ }^{1}$, A. Saiz-Lopez ${ }^{3}$, C. E. Jones ${ }^{4}$, \\ L. J. Carpenter ${ }^{4}$, and G. B. McFiggans ${ }^{5}$ \\ ${ }^{1}$ School of Chemistry, University of Leeds, Leeds LS2 9JT, UK \\ ${ }^{2}$ Instituto Nacional de Meteorologia Geofisica (INMG), Delegação de São Vicente, Monte, CP 15, Mindelo, Cape Verde \\ ${ }^{3}$ Laboratory of Atmospheric and Climate Science, Consejo Superior de Investigaciones Cientificas, 45007 Toledo, Spain \\ ${ }^{4}$ Department of Chemistry, University of York, York, UK \\ ${ }^{5}$ Centre for Atmospheric Science, School of Earth, Environment and Environmental Sciences, The University of Manchester, \\ Manchester, M13 9PL, UK
}

Received: 23 October 2009 - Published in Atmos. Chem. Phys. Discuss.: 12 November 2009

Revised: 12 April 2010 - Accepted: 25 April 2010 - Published: 19 May 2010

\begin{abstract}
Although tropospheric reactive halogen chemistry is well studied in coastal and polar environments, the presence of halogens over the open ocean environment has not been widely reported. The impacts of halogens on the tropical open ocean marine boundary layer (MBL), in particular, are not well characterised. This paper describes observations of iodine monoxide (IO) and bromine oxide $(\mathrm{BrO})$ over eight months in the tropical open ocean MBL, on the north-eastern side of São Vicente (Cape Verde Islands, $\left.16.85^{\circ} \mathrm{N}, 24.87^{\circ} \mathrm{W}\right)$. The highest $\mathrm{BrO}$ mixing ratio observed was $5.6 \pm 1 \mathrm{pmol} \mathrm{mol}^{-1}$, while the maximum observed IO mixing ratio was $3.1 \pm 0.4 \mathrm{pmol} \mathrm{mol}^{-1}$. The average values seen between 09:00-17:00 GMT were $\sim 2.8 \mathrm{pmol} \mathrm{mol}^{-1}$ for $\mathrm{BrO}$ and $\sim 1.5 \mathrm{pmol} \mathrm{mol}^{-1}$ for IO; these averages showed little variability over the entire campaign from November 2006 to June 2007. A 1-dimensional chemistry and transport model is used to study the evolution of iodine species and quantify the combined impact of iodine and bromine chemistry on the oxidising capacity of the MBL. It appears that the measured fluxes of iodocarbons are insufficient to account for the observed levels of IO, and that an additional I atom source is required, possibly caused by the deposition of $\mathrm{O}_{3}$ onto the ocean surface in the presence of solar radiation. Modelling results also show that the $\mathrm{O}_{3}$ depletion observed at Cape Verde cannot be explained in the absence of halogen chemistry, which contributes $\sim 45 \%$ of the observed
\end{abstract}

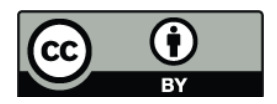

Correspondence to: A. S. Mahajan (anoop.mahajan@ciac.jccm-csic.es)
$\mathrm{O}_{3}$ depletion at the height of measurements $(10 \mathrm{~m})$ during summer. The model also predicts that halogens decrease the hydroperoxy radical $\left(\mathrm{HO}_{2}\right)$ concentration by $\sim 14 \%$ and increase the hydroxyl radical $(\mathrm{OH})$ concentration by $\sim 13 \%$ near the ocean surface. The oxidation of dimethyl sulphide (DMS) by BrO takes place at a comparable rate to oxidation by $\mathrm{OH}$ in this environment. Finally, the potential of iodine chemistry to form new particles is explored and conditions under which particle formation could be important in the remote MBL are discussed.

\section{Introduction}

Catalytic cycles involving halogen radicals have been shown to deplete ozone in different regions of the atmosphere. In the 1970s, chlorine chemistry was shown to be the cause of stratospheric ozone depletion (e.g., Molina and Rowland, 1974; Stolarsky and Cicerone, 1974), while over the last three decades bromine chemistry has been shown to cause $\mathrm{O}_{3}$ depletion events (ODEs) in the polar tropospheric boundary layer (BL) in the Arctic and Antarctic (e.g., Bottenheim et al., 1986; Barrie et al., 1988; Kreher et al., 1997; Tuckermann et al., 1997; Wessel et al., 1998; Frieß et al., 2004; Jones et al., 2006; Saiz-Lopez et al., 2007a). Iodine also occurs at substantial $\mathrm{O}_{3}$-depleting levels in coastal Antarctica BL (Saiz-Lopez et al., 2007a) and satellite studies show that it can be widespread across the Antarctic continent (SaizLopez et al., 2007b, Schönhardt et al., 2008). Only recently have reactive iodine species been observed at very low levels

Published by Copernicus Publications on behalf of the European Geosciences Union. 
in the Arctic BL (Mahajan et al., 2009a), although it has been observed earlier in the Arctic troposphere (Wittrock et al., 2000). Halogens can also affect the $\mathrm{HO}_{\mathrm{x}}$ ratio (i.e., $\left[\mathrm{HO}_{2}\right] /[\mathrm{OH}]$ ) and $\mathrm{NO}_{\mathrm{x}}$ ratio (i.e., $\left.\left[\mathrm{NO}_{2}\right] /[\mathrm{NO}]\right)$. $\mathrm{XO}$ (where $\mathrm{X}=\mathrm{Br}, \mathrm{I}$ ) radicals oxidise $\mathrm{NO}$ to $\mathrm{NO}_{2}$, thus increasing the $\mathrm{NO}_{\mathrm{x}}$ ratio, while they react with $\mathrm{HO}_{2}$ to yield $\mathrm{HOX}$, which on photolysis produces $\mathrm{OH}$ (e.g. for $\mathrm{HOI}$, the lifetime against photolysis at midday in the tropics is $\sim 1.5 \mathrm{~min}$ ), thus decreasing the $\mathrm{HO}_{\mathrm{x}}$ ratio (e.g., Bloss et al., 2005; von Glasow and Crutzen, 2007). In the mid-latitude MBL, BrO has been shown to oxidise DMS up to an order of magnitude faster than OH (Saiz-Lopez et al., 2004; von Glasow et al., 2004). Bromine and iodine chemistry also play a central role in the oxidation of elemental mercury $\left(\mathrm{Hg}^{0}\right)$ in the polar atmosphere (Schroeder et al., 1998; Brooks et al., 2006; SaizLopez et al., 2008). Finally, in the coastal MBL, iodine oxides are also implicated in the formation of ultra-fine aerosol, although the exact mechanism is still not understood (e.g., O'Dowd et al., 1998; Hoffmann et al., 2001; Mäkelä et al., 2002; Jimenez et al., 2003; Burkholder et al., 2004; McFiggans et al., 2004; Saunders and Plane, 2005; Sommariva et al., 2006).

The main sources of reactive halogen species can be biogenic emissions of photolabile halocarbons (e.g., Theiler et al., 1978; Wever et al., 1991; Carpenter et al., 1999; Gebhardt et al., 2008) and molecular $\mathrm{I}_{2}$ (Saiz-Lopez and Plane, 2004), emissions from sea-salt, sea-ice and the ocean surface through acid catalysed reactions or uptake of halogen nitrates (e.g. Behnke et al., 1994; Vogt et al., 1996; Sander and Crutzen, 1996; Abbatt and Nowak, 1997; Fickert et al., 1999; Wennberg, 1999), volcanic emissions (Bobrowski et al., 2003; Lee et al., 2005) and finally anthropogenic emissions (e.g., Andreae et al., 1996; Gabriel et al., 2002). Laboratory experiments have also shown that ozone deposition could play an important role in the emission of halogen compounds, especially iodine from seawater (Garland and Curtis, 1981; Mochida et al., 2000; Martino et al., 2009; Sakamoto et al., 2009).

Relatively high $\mathrm{BrO}$ mixing ratios $\left(>10 \mathrm{pmol} \mathrm{mol}^{-1}\right)$ are consistently reported in the springtime polar BL (e.g., Hausmann and Platt, 1994; Tuckermann et al., 1997; Richter et al., 1998; Saiz-Lopez et al., 2007a; Wagner and Platt, 1998). $\mathrm{BrO}$ has also been measured on a regional scale above salt lakes and in volcanic plumes (Hebestreit et al., 1999; Stutz et al., 2002; Bobrowski et al., 2003). In the mid-latitude MBL, $\mathrm{BrO}$ has been positively detected only at three coastal locations: Leser et al. (2003) observed variable levels around the Canary Islands peaking at $2.4 \mathrm{pmol} \mathrm{mol}^{-1}$, Saiz-Lopez et al. (2004) saw post sunrise peak levels of $\sim 6 \mathrm{pmol} \mathrm{mol}^{-1}$ with an average of $2 \mathrm{pmol} \mathrm{mol}^{-1}$ over the day at Mace Head, Ireland, while Mahajan et al. (2009b) reported elevated BrO mixing ratios peaking at $7.5 \mathrm{pmol} \mathrm{mol}^{-1}$ in the semi-polluted coastal environment at Roscoff, France. Modelling studies have predicted background $\mathrm{BrO}$ levels of $1-4 \mathrm{pmol} \mathrm{mol}^{-1}$ (Vogt et al., 1996; von Glasow et al., 2002a). Upper lim- its have also been reported where $\mathrm{BrO}$ was not seen above the instrumental detection limit. Theys et al. (2007) reported $\mathrm{BrO}$ in the free troposphere (FT) around the Reunion Island with an upper limit of $0.5 \mathrm{pmol} \mathrm{mol}^{-1}$ in the BL. Hönninger (2002) also calculated that $\mathrm{BrO}$ around Crete was less than $1.5 \mathrm{pmol} \mathrm{mol}^{-1}$, while Peters et al. (2005) reported an upper limit of $2 \mathrm{pmol} \mathrm{mol}^{-1}$ from Lilia, on the coast of Brittany, France.

In the MBL, IO was first detected at Mace Head, Ireland by Alicke et al. (1999). Since then, measurements at a variety of sub-tropical and temperate coastal locations have reported IO levels up to $\sim 27 \mathrm{pmol} \mathrm{mol}^{-1}$ (e.g., Allan et al., 2000; Frieß et al., 2001; Saiz-Lopez and Plane, 2004; Zingler and Platt, 2005; Peters et al., 2005; Stutz et al., 2007; Whalley et al., 2007; Mahajan et al., 2009c). Upper limits for IO have been reported at other locations: $0.8 \mathrm{pmol} \mathrm{mol}^{-1}$ at Crete (Hönninger, 2002), $2 \mathrm{pmol} \mathrm{mol}^{-1}$ at Ny-Ålysund (Wittrock et al., 2000), and $2 \mathrm{pmol} \mathrm{mol}^{-1}$ at Kuujjuarapik, Canada (Hönninger et al., 2004). In contrast, IO has been observed in excess of $20 \mathrm{pmol} \mathrm{mol}^{-1}$ in coastal Antarctica during springtime (Saiz-Lopez et al., 2007a), and satellite measurements have shown that IO can be detected over large areas in and around the continent (Saiz-Lopez et al., 2007b; Schönhardt et al., 2008). Observations of other iodine compounds such as $\mathrm{I}_{2}$ and OIO are not as common as $\mathrm{BrO}$ or IO. OIO was first detected at Cape Grim (Tasmania) by Allan et al. (2001), while the first measurement of $I_{2}$ was made by Saiz-Lopez and Plane (2004) at Mace Head. OIO has since been measured in other coastal locations (e.g. Peters et al., 2005; Stutz et al., 2007; Mahajan et al., 2009c), while positive detection of $\mathrm{I}_{2}$ has been made at only two other locations, Malibu, California (Finley and Saltzman, 2008) and Roscoff, Brittany (Mahajan et al., 2009c).

A recent study at the Cape Verde Islands reported the presence of both $\mathrm{BrO}$ and IO at mixing ratios of $1-3 \mathrm{pmol} \mathrm{mol}^{-1}$, and indicated that the observed ozone depletion during the same campaign could not be explained in the absence of halogen compounds (Read et al., 2008). The importance of this study is that this was arguably the first measurement of these halogen radicals in the mid-ocean MBL where local biological sources (such as macroalgae exposed at low tide) were unimportant, and hence may be representative of halogen activity over much of the open ocean (Read et al., 2008). In the present paper, we consider these halogen oxide measurements at Cape Verde in further detail, using a 1-D model to investigate the source strengths and likely vertical distributions of iodine species in the tropical Atlantic MBL. We then explore the effects of combined iodine and bromine chemistry on $\mathrm{O}_{3}$ depletion, the $\mathrm{HO}_{\mathrm{x}}$ ratio and the lifetime of DMS. Finally, we consider the potential for iodine oxides to form new particles which may grow to become cloud condensation nuclei $(\mathrm{CCN})$ in this environment. 


\section{Experimental}

DOAS measurements of $\mathrm{BrO}$ and $\mathrm{IO}$ were made at Cape Verde for a period of eight months from November 2006 to June 2007, as part of the UK Surface Ocean Lower Atmosphere Study (SOLAS) programme. During this period, the instruments were located at the Cape Verde Atmospheric Observatory $(\mathrm{CVAO})\left(16.85^{\circ} \mathrm{N}, 24.87^{\circ} \mathrm{W}\right)$, on the north-eastern side of the island of São Vicente. Further details about the observatory and the prevalent meteorological conditions can be found elsewhere (Lee et al., 2010). The long-path DOAS instrument (LP-DOAS) was placed in a temperature-controlled sea freight container at the observatory. The optical path ran across the bay, where a retro-reflector array was placed at a distance of $6 \mathrm{~km}$ from the measurement site (Supporting online text Fig. S1 http://www.atmos-chem-phys.net/10/4611/ 2010/acp-10-4611-2010-supplement.pdf), resulting in a total optical path length of $12 \mathrm{~km}$. The light beam was $\sim 10 \mathrm{~m}$ above the ocean surface. Further details on the LP-DOAS and the deconvolution procedure used can be found elsewhere (Plane and Saiz-Lopez, 2006). Briefly, the recorded spectra were converted into optical densities, and the contributions of the individual absorbing species were then determined by using singular value decomposition to fit simultaneously a library of reference absorption cross-sections. For the retrieval of $\mathrm{BrO}$, the $324-357 \mathrm{~nm}$ spectral window was used, while IO was retrieved in the $425-445 \mathrm{~nm}$ window. Reference spectra included in the fitting routine for retrieving $\mathrm{BrO}$ were: $\mathrm{BrO}$ (Wilmouth et al., 1999), $\mathrm{NO}_{2}$ (Vandaele et al., 1998), $\mathrm{O}_{3}$ (Daumont et al., 1992), HONO (Bongartz et al., 1991) and HCHO (Cantrell et al., 1990). For retrieving IO, reference spectra were: IO (Gómez Martin et al., 2005), $\mathrm{NO}_{2}$ (Harder et al., 1997) and $\mathrm{H}_{2} \mathrm{O}$ (Rothman et al., 2003). An example of the quality of the fits, along with averaged diurnal and annual measurements are presented elsewhere (Read et al., 2008).

During the summer of 2007 (May), an intensive campaign took place at the observatory as a part of the Reactive Halogens in the Marine Boundary Layer (RHaMBLe) project. The details of the instruments deployed during this period can be found in Lee et al. (2010). Along with other ancillary measurements, the intensive campaign also involved a research aircraft that measured composition over the site to assess how representative of the overlying BL it was and to determine any diurnal variability in BL depth. Additionally, a ship-based study measured the fluxes of halocarbons above the ocean surface around Cape Verde and over the upwelling region near Mauritania during the same period (Jones et al., in preparation).
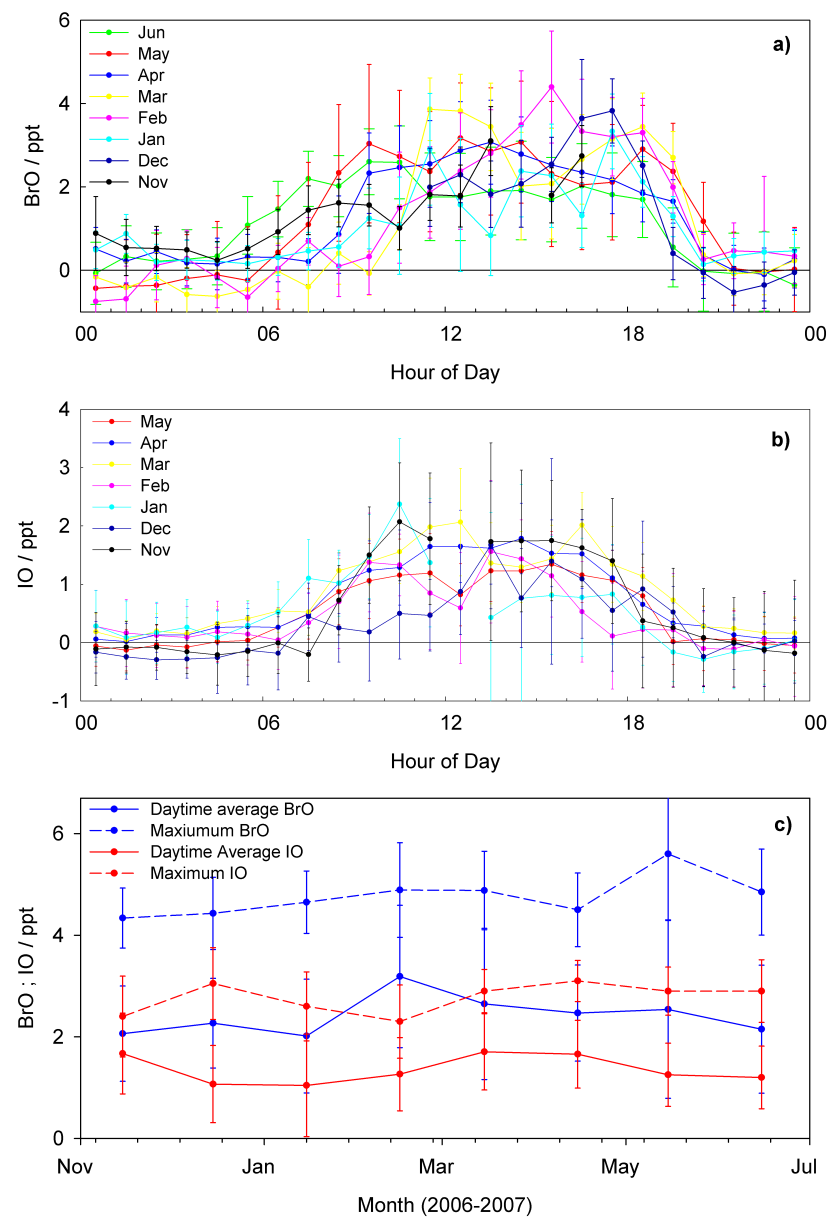

Fig. 1. The monthly averaged diurnal profiles for $\mathrm{IO}$ and $\mathrm{BrO}$ are shown in panels (a) and (b). Both radicals show a distinctive tophat profile with the highest mixing ratios measured between 09:0017:00 GMT. The average annual profile of IO and BrO along with the highest measured mixing ratio for each month is shown in panel (c) indicating little annual variability. Local noon is at GMT-1. The average detection limits were $\mathrm{BrO}: 0.5-1.0 \mathrm{pmol} \mathrm{mol}^{-1}$ and IO: $0.3-0.5 \mathrm{pmol} \mathrm{mol}^{-1}$.

\section{Observations}

$\mathrm{BrO}$ was detected on a total of 38 days, while $\mathrm{IO}$ was detected on 56 days over the duration of the campaign. The maximum $\mathrm{BrO}$ mixing ratio observed was $5.6 \pm 1 \mathrm{pmol} \mathrm{mol}^{-1}$ (27 May 2007), while the maximum IO mixing ratio observed was $3.1 \pm 0.4 \mathrm{pmol} \mathrm{mol}^{-1}$ (15 April 2007). Figure 1a and $\mathrm{b}$ illustrate the measured monthly-averaged diurnal profiles of $\mathrm{BrO}$ and $\mathrm{IO}$, respectively, for the eight months of the campaign. $\mathrm{BrO}$ and $\mathrm{IO}$ were observed above the detection limit whenever the solar zenith angle was less than $\sim 92^{\circ}$, i.e., twilight and full daylight conditions. Although there was considerable day-to-day variation throughout the campaign (higher temporal resolution data in supporting online material, Figs. S2-S9 http://www.atmos-chem-phys.net/ 

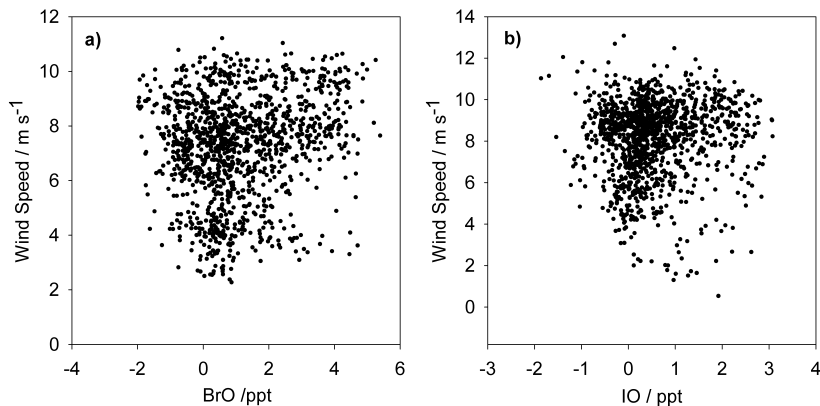

Fig. 2. Correlation of $\mathrm{BrO}$ and $\mathrm{IO}$ with wind speed at São Vicente. Panel (a) shows the correlation for $\mathrm{BrO}$ and (b) show a similar plot for IO. There is no significant correlation for either species: for $[\mathrm{BrO}]$ vs. wind speed, linear regression through the data has an $R^{2}=0.02$, while for [IO] vs. wind speed, $R^{2}=0.003$.

10/4611/2010/acp-10-4611-2010-supplement.pdf), it can be seen that the profiles exhibit a "top-hat" distribution, with the mixing ratios roughly representing a plateau showing little change between 09:00-17:00 GMT. On averaging the data over the entire campaign, both species show similar diurnal profiles dependent on solar radiation, with mixing ratios below the detection limits (BrO: $0.5-0.8 \mathrm{pmol} \mathrm{mol}^{-1}$, IO: $0.3-0.5 \mathrm{pmol} \mathrm{mol}^{-1}$ ) at night and average peak values of $\sim 2.8 \mathrm{pmol} \mathrm{mol}^{-1} \mathrm{BrO}$ and $\sim 1.5 \mathrm{pmol} \mathrm{mol}^{-1}$ IO during the daytime (Read et al., 2008). The monthly daytime-averaged values between 09:00 and 17:00 GMT, and the maximum observed mixing ratios in each month of the campaign, are shown for both species in Fig. 1c. There is clearly very little seasonal variation: although there is some hint of slightly higher values during spring (February-May), this is not significant within the variability of the observations.

The $\mathrm{BrO}$ and $\mathrm{IO}$ mixing ratios do not show a strong correlation with the origin of the air masses given by the air mass back trajectories, the wind direction or the wind speed. Figure 2 shows the variation of $\mathrm{BrO}$ and $\mathrm{IO}$ with wind speed. There is no significant correlation for either species: for [BrO] vs. wind speed, linear regression through the data has a slope of $0.21 \pm 0.04$ and $R^{2}=0.02$, while for [IO] vs. wind speed the slope was $0.12 \pm 0.06$ and $R^{2}=0.003$. In the case of $\mathrm{BrO}$, all measurements were made when the wind happened to be from the prevailing north-easterly direction, and hence a correlation analysis cannot be made. In the case of IO, although the wind direction did vary, there does not appear to be clear dependence on wind direction.

Finally, the LP-DOAS was also periodically configured to measure other iodine species ( $\mathrm{I}_{2}$ and $\left.\mathrm{OIO}\right)$, as well as the night-time radical $\mathrm{NO}_{3}$. All three species were below the detection limit of the instrument throughout the campaign i.e. $\left[\mathrm{I}_{2}\right] \leq 15 \mathrm{pmol} \mathrm{mol}^{-1}$, $[\mathrm{OIO}] \leq 10 \mathrm{pmol} \mathrm{mol}^{-1}$, and $\left[\mathrm{NO}_{3}\right] \leq 4 \mathrm{pmol} \mathrm{mol}^{-1}$.

\section{Discussion and modelling}

\subsection{Bromine chemistry}

The release of inorganic bromine from sea-salt aerosols and its impact on the remote MBL has been studied in some detail in previous work (Sander et al., 2003; Vogt et al., 1996; von Glasow et al., 2002a; von Glasow et al., 2002b; von Glasow et al., 2004). Some model studies for the acidcatalysed activation of bromine from sea-salt aerosol have predicted $\mathrm{BrO}$ mixing ratios in the MBL ranging from 1$4 \mathrm{pmol} \mathrm{mol}^{-1}$, with a diurnal top-hat variation (Vogt et al., 1996; vonGlasow et al., 2002a; Yang et al., 2005). This is due to the removal of $\mathrm{BrO}$ via the reaction with $\mathrm{HO}_{2}$ to form $\mathrm{HOBr}$, which peaks at midday and limits the build up of $\mathrm{BrO}$. Box model calculations for conditions seen at Cape Verde show that to sustain an average $[\mathrm{BrO}]$ of $\sim 2.8 \mathrm{pmol} \mathrm{mol}^{-1}$, there needs to be a total gas-phase bromine loading of $\sim 10 \mathrm{pmol} \mathrm{mol}^{-1}$. Considering that the $\left[\mathrm{Br}^{-}\right] /\left[\mathrm{Cl}^{-}\right]$ratio in fresh aerosols is $\sim 1.5 \times 10^{-3} \mathrm{~mol} \mathrm{~mol}^{-1}$, reflecting the sea water ratio of 1:660 (Wilson, 1975), and assuming an increased salinity of $320 \mathrm{~g} \mathrm{l}^{-1}$ due to evaporation of water from sea-salt aerosols, the maximum amount of bromide available in $20 \mu^{3} \mathrm{~cm}^{-3}$ of wet aerosol volume (Allan et al., 2009) would be $\sim 4 \mathrm{pmol} \mathrm{mol}^{-1}$. Hence, continuous replenishment of aerosols and depletion of bromide from these aerosols would explain the levels of $\mathrm{BrO}$ seen at Cape Verde considering the long lifetime of bromine in the gas phase ( $~ 10 \mathrm{~d}$ in the tropics; vonGlasow et al., 2004). $\mathrm{Br}^{-}$depletion in aerosols can occur through acid-catalysed reactions, which are pH-dependent (Mozurkewich, 1995; Abbatt and Waschewsky, 1998; Fickert et al., 1999). $\mathrm{Br}^{-}$depletion in aerosols has been reported previously (Gabriel et al., 2002; Newberg et al., 2005). Furthermore, measurements of total gaseous inorganic $\mathrm{Br}$ made at Cape Verde during May 2007 indicate that the total inorganic $\mathrm{Br}$ present at Cape Verde was as high as $12 \mathrm{pmol} \mathrm{mol}^{-1}$ (A. A. P. Pszenny, University of New Hampshire and W. C. Keene, University of Virginia, personal communication, 2009), indicating that the observed $\mathrm{BrO}$ levels can satisfactorily be explained through emissions from sea-salt aerosol. It should be noted that recent measurements in the tropical Atlantic Ocean have reported [BrO] peaking at $10.2 \mathrm{nmol} \mathrm{mol}^{-1}$ near the African coast, suggesting other possible sources (Martin et al., 2009). Since the focus of the modelling study described below is iodine chemistry, we will therefore not explicitly model bromine aerosol chemistry here. Instead, the model will be constrained with the $\mathrm{BrO}$ observations, and then used to explore the iodine source required to replicate the IO measurements and to study the combined impact of iodine and bromine chemistry on $\mathrm{O}_{3}, \mathrm{HO}_{\mathrm{x}}$ and DMS chemistry. [BrO] is set to peak at $2.8 \mathrm{pmol} \mathrm{mol}^{-1}$ with a daytime profile showing little change in mixing ratios from 09:00-17:00 GMT according to observations at Cape Verde and is considered to be well mixed in the boundary layer due to the long lifetime of inorganic 
bromine in the gas phase, which is $\sim 10$ days in the tropics (von Glasow et al., 2004).

\subsection{Iodine chemistry}

Measurements and modelling studies of IO over the open ocean are rare, and the impacts of iodine chemistry on the remote oceanic environment have not been studied in detail. Although the levels of IO reported here are in accord with previous measurements along the coasts of Tenerife and Tasmania (Allan et al., 2000), no studies have been performed in the tropical remote MBL and to our knowledge these are the first measurements of reactive iodine species (RIS) over the tropical open ocean. The presence of IO above the detection limit of the instrument $\left(0.3-0.5 \mathrm{pmol} \mathrm{mol}^{-1}\right)$ at Cape Verde is surprising as the sources of iodine are assumed to be mainly biogenic. Although the oceans around Cape Verde are biologically active (Fallowski, 1997), there are no large macroalgal beds around São Vicente due to its steep shelf. Hence, it is probable that these waters represent a large area of elevated iodine emissions, possibly much of the tropical open oceans. A recent study by Martino et al. (2009) has suggested that deposition of $\mathrm{O}_{3}$ on the ocean surface could lead to the emission of iodocarbons in the presence of dissolved organic matter, which on photolysis could contribute to RIS in the MBL. Fluxes of iodocarbons measured over the open ocean close to the measurement site, as a part of the RHaMBLe campaign, confirm their presence (Jones et al., 2010) and indicate that they could indeed act as a source of RIS in the remote MBL.

The Tropospheric HAlogen chemistry MOdel (THAMO) is now employed to test whether the levels of IO seen at Cape Verde can be explained by the measured iodocarbon fluxes. Further details about THAMO can be found in Saiz-Lopez et al. (2008). Briefly, it is a 1-D chemistry transport model with 200 stacked boxes at a vertical resolution of $5 \mathrm{~m}$ (total height $1 \mathrm{~km})$. The model treats iodine, bromine, $\mathrm{O}_{3}, \mathrm{NO}_{\mathrm{x}}$ and $\mathrm{HO}_{\mathrm{x}}$ chemistry using 210 reactions. The chemical scheme used for this study is from Saiz-Lopez et al. (2008) and is updated according to Mahajan et al. (2009c). The model is constrained with typical measured values of other chemical species: $[\mathrm{CO}]=110 \mathrm{nmol} \mathrm{mol}^{-1} ; \quad[\mathrm{DMS}]=30 \mathrm{pmol} \mathrm{mol}^{-1}$; $\left[\mathrm{CH}_{4}\right]=1820 \mathrm{nmol} \mathrm{mol}^{-1} ; \quad[$ ethane $]=925 \mathrm{pmol} \mathrm{mol}^{-1}$; $\left[\mathrm{CH}_{3} \mathrm{CHO}\right]=970 \mathrm{pmol} \mathrm{mol}^{-1} ; \quad[\mathrm{HCHO}]=500 \mathrm{pmol} \mathrm{mol}^{-1}$ (measured during summer by the LP-DOAS at the CVAO); [isoprene] $=10 \mathrm{pmol} \mathrm{mol}^{-1} ; \quad[$ propane $]=60 \mathrm{pmol} \mathrm{mol}^{-1}$; [propene] $=20 \mathrm{pmol} \mathrm{mol}^{-1}$ (Read et al., 2008; Lee et al., 2010; Read et al., 2009). Wind speed measurements collected at three heights $(4,10$ and $30 \mathrm{~m})$ were used to construct an eddy diffusion coefficient $\left(K_{z}\right)$ profile (Stull, 1988), shown in the supporting online text (Fig. S10 http://www.atmos-chem-phys.net/10/4611/ 2010/acp-10-4611-2010-supplement.pdf). The average background aerosol surface area (ASA) used is $1 \times 10^{-6} \mathrm{~cm}^{2} \mathrm{~cm}^{-3}$, an average value estimated from Allan et al. (2009). During the RHaMBLe campaign, aircraft measurements of temperature in the BL revealed a strong temperature inversion about $1 \mathrm{~km}$ from the surface (Read et al., 2008), indicating that the BL at Cape Verde is decoupled from the free troposphere. Hence, the $K_{z}$ profile is assumed to increase up to a height of $30 \mathrm{~m}$ (where it peaks at $\left.3 \times 10^{4} \mathrm{~cm}^{2} \mathrm{~s}^{-1}\right)$, after which it decreases at a constant rate to a value of $2 \mathrm{~cm}^{2} \mathrm{~s}^{-1}$ at the top of the BL (Fig. S10 http://www.atmos-chem-phys.net/10/4611/2010/ acp-10-4611-2010-supplement.pdf). The sensitivity of the model to the $K_{z}$ profile is discussed later. The model is used to replicate the average levels of IO seen during May as there was a suite of other trace gas measurements made during this period (Lee et al., 2010), although it should be noted that there was little variability in the diurnal profiles of $\mathrm{IO}$ and $\mathrm{BrO}$ throughout the campaign (Fig. 1). The model is initialised at midnight and the evolution of iodine species, $\mathrm{O}_{3}, \mathrm{NO}_{\mathrm{x}}$ and $\mathrm{HO}_{\mathrm{x}}$ is followed for a period of $48 \mathrm{~h}$.

Initially, the injection of iodine into the model is constrained using the average sea-air iodocarbon fluxes measured over the open ocean close to Cape Verde (Jones et al., 2010): $\mathrm{CH}_{2} \mathrm{I}_{2}=13.0 \mathrm{nmol} \mathrm{m}^{-2} \mathrm{~d}^{-1}$, $\mathrm{CH}_{2} \mathrm{IBr}=10.9 \mathrm{nmol} \mathrm{m}^{-2} \mathrm{~d}^{-1}, \mathrm{CH}_{2} \mathrm{ICl}=16.2 \mathrm{nmol} \mathrm{m}^{-2} \mathrm{~d}^{-1}$, $\mathrm{CH}_{3} \mathrm{I}=48.5 \mathrm{nmol} \mathrm{m}^{-2} \mathrm{~d}^{-1}, \quad \mathrm{C}_{2} \mathrm{H}_{5} \mathrm{I}=4.1 \mathrm{nmol} \mathrm{m}^{-2} \mathrm{~d}^{-1}$ and $1-\mathrm{C}_{3} \mathrm{H}_{7} \mathrm{I}=0.9 \mathrm{nmol} \mathrm{m}^{-2} \mathrm{~d}^{-1}$. The predicted vertical profiles of the iodocarbons are shown in the supporting online text (Fig. S11 http://www.atmos-chem-phys.net/10/4611/ 2010/acp-10-4611-2010-supplement.pdf). The longer lived iodocarbons (e.g. $\mathrm{C}_{2} \mathrm{H}_{5} \mathrm{I}$ ) are better mixed through the $\mathrm{BL}$, but the more photo-labile iodocarbons show a strong diurnal profile and are limited to $<300 \mathrm{~m}\left(\mathrm{CH}_{2} \mathrm{I}_{2}, \mathrm{CH}_{2} \mathrm{IBr}, \mathrm{CH}_{2} \mathrm{ICl}\right)$. Using these measured iodocarbon fluxes, the predicted levels of daytime IO are only $\sim 30 \%$ of the observed values, peaking at only $0.45 \mathrm{pmol} \mathrm{mol}^{-1}$ compared to the average observed value of around $1.5 \mathrm{pmol} \mathrm{mol}^{-1}$ (Fig. 3). The predicted daytime $\mathrm{O}_{3}$ depletion is only $\sim 2.9 \mathrm{nmol} \mathrm{mol}^{-1}$, compared to an observed decrease of $\sim 4.5 \mathrm{nmol} \mathrm{mol}^{-1}$ observed at Cape Verde during May 2007 (Read et al., 2008). Additionally, the diurnal profile indicates that the IO should peak later in the evening (Fig. 3) due to a slow release of I atoms resulting from the relatively long lifetime of the iodocarbons (e.g. $\mathrm{CH}_{2} \mathrm{IBr}=\sim 15 \mathrm{~min}, \mathrm{CH}_{2} \mathrm{ICl}=\sim 1 \mathrm{~h}$, $\mathrm{CH}_{3} \mathrm{I}=23 \mathrm{~h}$ at midday) and hence slow build-up of $\mathrm{IO}$ during the daytime, in contrast to the observed top-hat profile (Figs. 1 and 3).

These modelling results show that an additional flux of iodine is necessary in order to reproduce the observed levels of IO, as the iodocarbons can account for around one third of the observed IO mixing ratio. In the model, this additional source is considered to be in the form of an $\mathrm{I}_{2}$ flux from the sea. Several laboratory studies have shown that deposition of $\mathrm{O}_{3}$ on sea surface leads to the emission of $\mathrm{I}_{2}$ (Garland and Curtis, 1981; Sakamoto et al., 2009). If a constant day and night $\mathrm{I}_{2}$ flux of $5 \times 10^{7}$ molecules $\mathrm{cm}^{-2} \mathrm{~s}^{-1}$ is considered, the model predicts a peak of $1.6 \mathrm{pmol} \mathrm{mol}^{-1}$ of IO during the 

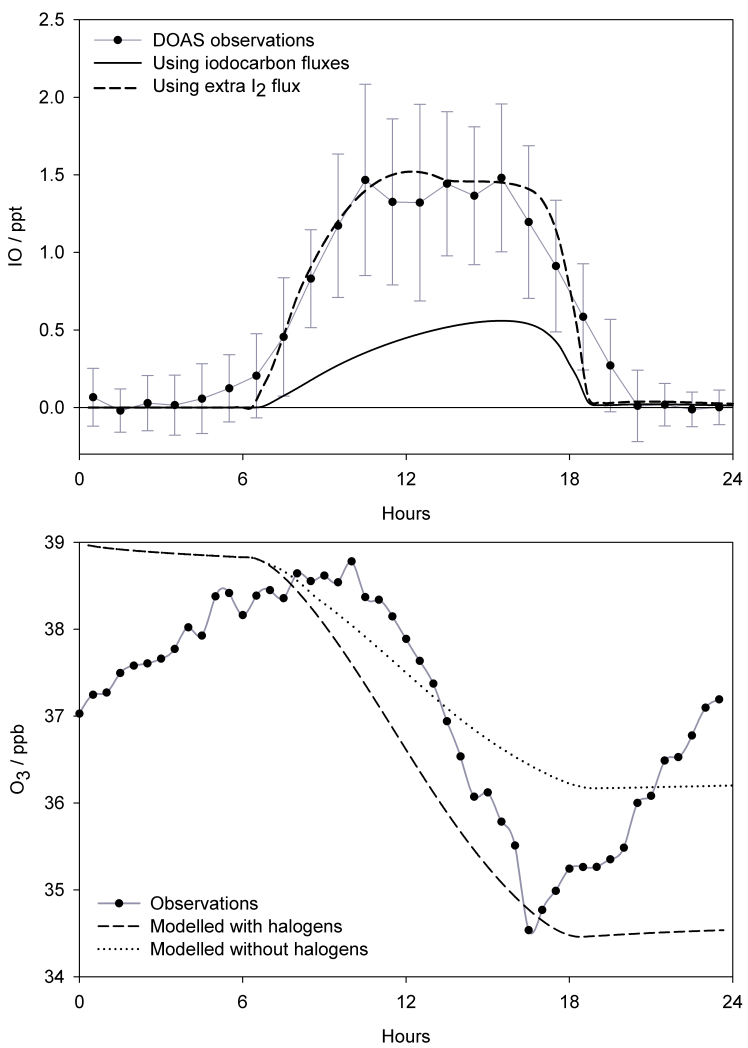

Fig. 3. Observed diurnal $\mathrm{IO}$ mixing ratios and $\mathrm{O}_{3}$ destruction during May 2007 at Cape Verde (Read et al., 2008) compared with model predicted $\mathrm{O}_{3}$ at the height of measurements $(10 \mathrm{~m})$. In the absence of halogens, the model predicts the loss of only $2.5 \mathrm{nmol} \mathrm{mol}{ }^{-1}$ in one day, while in the presence of halogens, this loss is $\sim 4.4 \mathrm{nmol} \mathrm{mol}^{-1}$. Local noon is at GMT-1.

day time, which is in agreement with the observations. In this scenario, the model also predicts a post-sunrise pulse of $\sim 1.4 \mathrm{pmol} \mathrm{mol}^{-1}$ lasting for about $20 \mathrm{~min}$. The best fit to the observed data is achieved by using a flux considered to be active only during the daytime. There is evidence for the photosensitized production of volatile halogen species at the sea surface (Reeser et al., 2009). If this source dominated (or worked in conjuction with) $\mathrm{O}_{3}$ deposition, it would account for a significant diurnal source of iodine. An $\mathrm{I}_{2}$ flux peaking at $5.7 \times 10^{8}$ molecule $\mathrm{cm}^{-2} \mathrm{~s}^{-1}$ is needed along with the measured iodocarbon flux to reproduce the observed IO. The diurnal profile of this flux is chosen to produce the IO observations and peaks between 09:00-00:00 GMT with zero emissions during the night time (supplementary online text Fig. S12 http://www.atmos-chem-phys.net/10/4611/ 2010/acp-10-4611-2010-supplement.pdf). Figure 4 shows the predicted diurnal vertical profiles for $\mathrm{IO}, \mathrm{O}_{3}, \mathrm{I}_{2}$ and OIO when this additional flux is included. Now, the levels of IO are in good accord with the observations at the height of measurements. The predicted vertical profile of IO shows a strong gradient with only $0.15 \mathrm{pmol} \mathrm{mol}^{-1}$
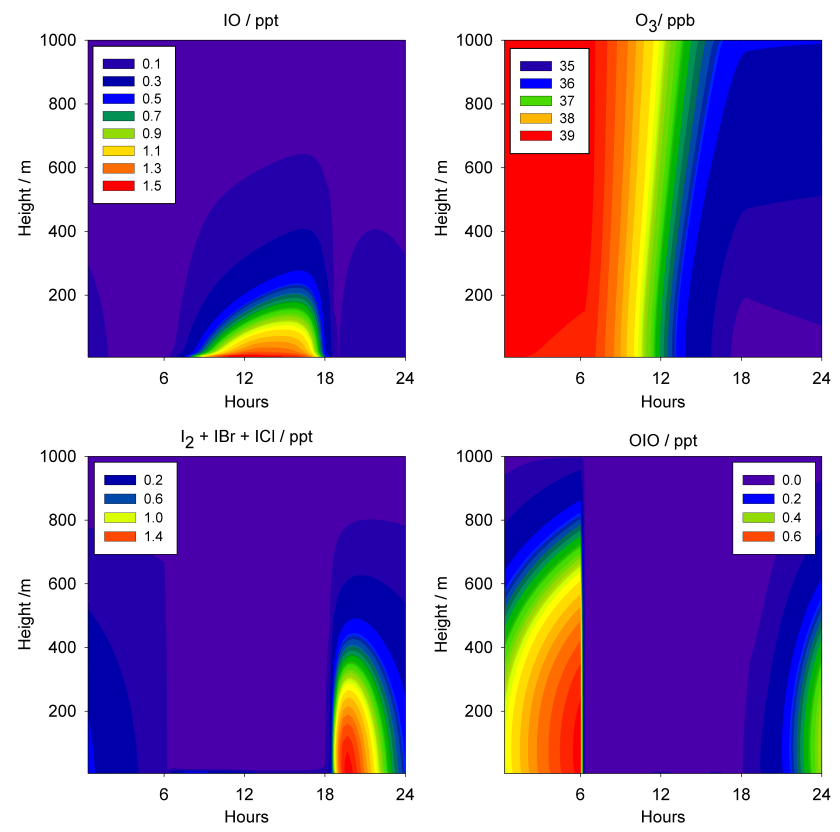

Fig. 4. Predicted profiles of $\mathrm{IO}, \mathrm{O}_{3},\left(\mathrm{I}_{2}+\mathrm{IBr}+\mathrm{ICl}\right)$ and $\mathrm{OIO}$ at Cape Verde using an extra $\mathrm{I}_{2}$ flux in addition to measured halocarbon fluxes. The IO mixing ratios are seen to peak at $1.5 \mathrm{pmol} \mathrm{mol}^{-1}$ at the height of measurements and are in good accord with the observed average of $\sim 1.5 \mathrm{pmol} \mathrm{mol}^{-1}$. The predicted $\mathrm{O}_{3}$ depletion is about $4.4 \mathrm{nmol} \mathrm{mol}^{-1}$ over one day, while the predicted $\mathrm{I}_{2}$ and OIO values are under the detection limit of the DOAS instrument $\left(\mathrm{I}_{2}-15 \mathrm{pmol} \mathrm{mol}^{-1}\right.$, OIO- $\left.10 \mathrm{pmol} \mathrm{mol}^{-1}\right)$. The model is initialised at midnight and the $\mathrm{IO}, \mathrm{OIO}$ and $\left(\mathrm{I}_{2}+\mathrm{IBr}+\mathrm{ICl}\right)$ data from 24-30 $\mathrm{h}$ has been shifted by $-24 \mathrm{~h}$ in order to illustrate the full diurnal cycle. Local noon is at GMT-1.

(10\%) seen at $500 \mathrm{~m}$ (Figs. 4 and 5). Even with the additional $\mathrm{I}_{2}$ flux, the $\mathrm{I}_{2}$ and OIO levels are under the detection limit throughout the BL. It should also be noted that even when using a continuous $\mathrm{I}_{2}$ flux, the $\mathrm{I}_{2} \mathrm{mix}$ ing ratio predicted by the model during the night at $10 \mathrm{~m}$ is still under the DOAS detection limit. The $K_{z}$ profile in Fig. S10 (http://www.atmos-chem-phys.net/10/4611/ 2010/acp-10-4611-2010-supplement.pdf) considers that the $K_{z}$ reduces with height after $30 \mathrm{~m}$ but the model was found to be sensitive to the height from which the $K_{z}$ is considered to decrease. For an extreme condition, we assume that the $K_{z}$ does not decrease with height, but stays constant after $30 \mathrm{~m}$. Using such a profile, the predicted [IO] at the height of measurements $(10 \mathrm{~m})$ is found to be $\sim 18 \%$ lower at the peak of the I atom flux due to faster mixing. However, no realistic diurnally-changing $K_{z}$ profile can reproduce the observed IO profile using only the iodocarbon fluxes.

Considering an $\mathrm{O}_{3}$ deposition velocity of $0.05 \mathrm{~cm} \mathrm{~s}^{-1}$ (Chang et al., 2004) and an $\mathrm{O}_{3}$ mixing ratio of $35 \mathrm{nmol} \mathrm{mol}^{-1}$ in the $\mathrm{BL}$, the total flux of $\mathrm{O}_{3}$ molecules into the ocean would be $4.3 \times 10^{10}$ molecules $\mathrm{cm}^{-2} \mathrm{~s}^{-1}$. If the deposition of $\mathrm{O}_{3}$ is responsible for the emission of I atoms from the 
ocean, this would mean that $\sim 3$ iodine atoms are emitted to the gas phase for every 100 molecules of $\mathrm{O}_{3}$ that are deposited on the ocean surface. One laboratory study has suggested that $20 \%$ of the $\mathrm{O}_{3}$ deposited to the ocean surface reacts with $\mathrm{I}^{-}$ions in seawater to form molecular iodine and suggested that a significant fraction of this evaporates from the ocean surface (Garland and Curtis, 1980). Furthermore, the best fit of the $\mathrm{I}_{2}$ flux to the measured IO diurnal profile requires that the emission of I atoms from the ocean surface is more active during the daytime (Fig. S12 http://www.atmos-chem-phys.net/10/4611/2010/ acp-10-4611-2010-supplement.pdf), which could indicate a photochemical production of $I_{2}$ or other iodocarbons in the sea-surface micro layer, perhaps coupled with the deposition of $\mathrm{O}_{3}$.

The vertical profile of iodine species is shown in Fig. 5. It can be seen that the IO mixing ratio drops to about $10 \%$ of the value at the surface in the first $500 \mathrm{~m}$, so that most of the IO is confined to the lower BL. The total column abundance predicted by the model is $9.7 \times 10^{11}$ molecules $\mathrm{cm}^{-2}$, which is below the upper limit of $2 \times 10^{12}$ molecules $\mathrm{cm}^{-2}$ for current satellite measurements (Schönhardt et al., 2007).

\subsection{Effect of halogens on ozone}

The vertical temperature profiles measured by the aircraft show a capped BL with a strong temperature inversion at about $1000 \mathrm{~m}$ during all the flights above Cape Verde indicating that the $\mathrm{BL}$ is decoupled from the free troposphere (Read et al., 2008). Read et al. also concluded that the MBL around Cape Verde is subject to minimal diurnal variations in dynamics because the temperature and wind speed are relatively constant. Furthermore, the free tropospheric $\mathrm{O}_{3}$ mixing ratios over Cape Verde were found to be significantly lower than in the BL (Read et al., 2008), indicating that $\mathrm{O}_{3}$ entrainment cannot take place into the BL directly above Cape Verde. $\mathrm{O}_{3}$ entrainment into the BL actually takes place around $200 \mathrm{~km}$ further north-east of the measurement site, where measurements show elevated $\mathrm{O}_{3}$ in the free troposphere (Lee et al., 2010); advection of air to Cape Verde then causes a rise in the $\mathrm{O}_{3}$ concentrations during the night (Read et al., 2008).

During the summer month of May, the average loss of $\mathrm{O}_{3}$ is $\sim 4.3 \mathrm{nmol} \mathrm{mol}^{-1} \mathrm{day}^{-1}$, although in the absence of halogens, the model predicts a loss of only $\sim 2.5 \mathrm{nmol} \mathrm{mol}^{-1}$ over the entire day at the height of measurements (Fig. 3). This calculated $\mathrm{O}_{3}$ loss is due to $\mathrm{HO}_{\mathrm{x}}$ chemistry and deposition to the ocean surface. If the observed levels of halogens are now included in the model, through emission of iodine as explained earlier ( $1.5 \mathrm{pmol} \mathrm{mol}^{-1} \mathrm{IO}$ and constrained $2.5 \mathrm{pmol} \mathrm{mol}^{-1} \mathrm{BrO}$ ), the calculated $\mathrm{O}_{3}$ depletion at the height of measurements increases to $\sim 4.5 \mathrm{nmol} \mathrm{mol}^{-1} \mathrm{day}^{-1}$ (Fig. 3). The catalytic cycles involving halogens cause an increased loss of $1.6 \mathrm{nmol} \mathrm{mol}^{-1} \mathrm{day}^{-1}$ and the total predicted $\mathrm{O}_{3}$ loss is now in good agreement with the ob-

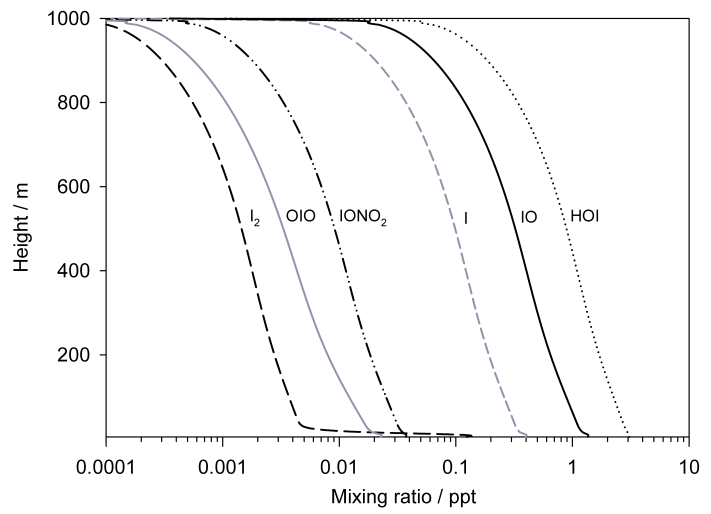

Fig. 5. Modelled vertical profiles of iodine species at Cape Verde are shown. The IO mixing ratios are seen to reduce to $10 \%$ at $500 \mathrm{~m}$, while OIO and $\mathrm{I}_{2}$ would be under the detection limit of the DOAS instrument $\left(\mathrm{I}_{2}-15 \mathrm{pmol} \mathrm{mol}^{-1}, \mathrm{OIO}-10 \mathrm{pmol} \mathrm{mol}^{-1}\right)$ all through the BL.

served loss. Figure 4 also shows that this observed depletion is well mixed in the BL with a maximum difference of $1.2 \mathrm{nmol} \mathrm{mol}^{-1}$ between the surface and at $1 \mathrm{~km}$. This prediction is confirmed by the aircraft measurements, which showed that $\mathrm{O}_{3}$ is well-mixed in the BL (Read et al., 2008). A point to note is the significant role that iodine chemistry plays in the $\mathrm{O}_{3}$ depletion. At midday, the $\mathrm{O}_{3}$ destruction rate due to iodine alone is $0.1 \mathrm{nmol} \mathrm{mol}^{-1}$ hour $^{-1}$, while the destruction due to bromine alone is $0.028 \mathrm{nmol} \mathrm{mol}^{-1}$ hour $^{-1}$. The combined impact of both halogens due to catalytic cycles involving $\mathrm{IO}$ and $\mathrm{BrO}$ (Gilles et al., 1997) destroys $\mathrm{O}_{3}$ at a rate of $0.19 \mathrm{nmol} \mathrm{mol}^{-1}$ hour $^{-1}$.

\subsection{Effect on $\mathrm{HO}_{\mathrm{x}}$}

In situ measurements of $\mathrm{OH}$ and $\mathrm{HO}_{2}$ were performed at Cape Verde during the RHaMBLe campaign using the LIF technique (Whalley et al., 2010). The measurements were made at the height of $10 \mathrm{~m}$ above sea level. Typical peak noon values of $0.25 \mathrm{pmol} \mathrm{mol}^{-1}$ and $18 \mathrm{pmol} \mathrm{mol}^{-1}$ were measured for $\mathrm{OH}$ and $\mathrm{HO}_{2}$, respectively. $\mathrm{BrO}$ and $\mathrm{IO}$ react with $\mathrm{HO}_{2}$ to form $\mathrm{HOBr}$ and $\mathrm{HOI}$, which on photolysis reproduce $\mathrm{OH}$, thus reducing the $\mathrm{HO}_{\mathrm{x}}$ ratio $\left(\mathrm{HO}_{2} / \mathrm{OH}\right)$ ratio. Figure 6 shows the effect of halogen chemistry on the vertical profile of $\mathrm{OH}$ and $\mathrm{HO}_{2}$, for scenarios with and without halogens. At the height of the measurements, the model scenario without halogen chemistry over-predicts $\mathrm{HO}_{2}$ by $\sim 14 \%$ of the measured concentration, and under-predicts the $\mathrm{OH}$ by $\sim 13 \%$. Thus, the modelled $\mathrm{HO}_{\mathrm{x}}$ ratio is 94 , compared with the measured ratio of 72 (Whalley et al., 2010). When halogen chemistry is included, the calculated $\mathrm{OH}$ and $\mathrm{HO}_{2}$ levels and diurnal profile are in agreement with the observations: the modelled ratio is now 76 . Figure 6 also shows that the vertical profile of $\mathrm{OH}$ and $\mathrm{HO}_{2}$ are significantly different when halogens are included in the model, with the lowest predicted $\mathrm{HO}_{\mathrm{x}}$ ratio closer to the surface, although at the top of the BL the effect of halogens is greatly reduced. 

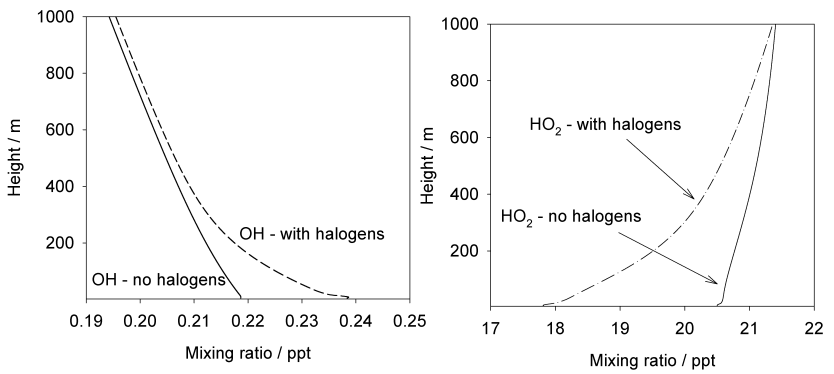

Fig. 6. Vertical profiles of modelled $\mathrm{OH}$ and modelled $\mathrm{HO}_{2}$ at Cape Verde for two scenarios: with and without halogen chemistry. At the height of the measurements, the model scenario without halogen chemistry over-predicts $\mathrm{HO}_{2}$ by $\sim 14 \%$ of the measured mixing ratio, and under-predicts the $\mathrm{OH}$ by $\sim 13 \%$. Average observed $\mathrm{OH}=0.25 \mathrm{pmol} \mathrm{mol}^{-1}$ and $\mathrm{HO}_{2}=18 \mathrm{pmol} \mathrm{mol}^{-1}$ (Whalley et al., 2009).

\subsection{DMS oxidation}

The role of $\mathrm{BrO}$ in the oxidation of DMS has been discussed previously (e.g., Toumi, 1994; Saiz-Lopez et al., 2004; von Glasow and Crutzen, 2004; von Glasow et al., 2004). In the tropical MBL, the loss of DMS is thought to take place mainly through oxidation by OH (Turnipseed et al., 1996). However, $\mathrm{BrO}$ and to a lesser extent, IO can also cause the oxidation of DMS in the MBL. At the levels of $\mathrm{BrO}$ and IO observed at Cape Verde, the oxidation of DMS by $\mathrm{BrO}$ is comparable to $\mathrm{OH}$ but that by $\mathrm{IO}$ is much lower (Table 1). The oxidation of DMS by halogen oxides forms dimethyl sulfoxide (DMSO), which is either rapidly lost to background aerosols or forms methyl sulfinic acid (MSIA) rather than $\mathrm{SO}_{2}$ and hence $\mathrm{H}_{2} \mathrm{SO}_{4}$. The presence of halogen oxides would therefore reduce the $\mathrm{CCN}$ formation potential of DMS if sulphuric acid formed from $\mathrm{OH}$ oxidation were assumed to build up to levels at which it would participate in nucleation (von Glasow and Crutzen, 2004).

\subsection{Iodine oxide particle (IOP) formation}

There are (at least) two major unresolved questions regarding IOPs: (i) the mechanism whereby iodine oxide molecules polymerize into sub-nm IOPs and (ii) the subsequent growth of these IOPs in the presence of condensable vapours (primarily water and acids) in the marine atmosphere. In the past, the oxidation of iodine oxides by $\mathrm{O}_{3}$ has been suggested to lead to the formation of $\mathrm{I}_{2} \mathrm{O}_{4}$ or $\mathrm{I}_{2} \mathrm{O}_{5}$, which can then polymerise to form IOPs (Jimenez et al., 2003; Saunders and Plane, 2005). However, very recent experiments at the University of Leeds show that IOPs are also produced from $\mathrm{IO}$ in the absence of $\mathrm{O}_{3}$ and hence oxidation of higher iodine oxides by ozone is not a requirement to form IOPs (Saunders et al., 2009). For the present model we have therefore omitted these $\mathrm{O}_{3}$ reactions. The new work at Leeds indicates that the particles form from the polymerization of
Table 1. Rates of DMS oxidation calculated for observations at Cape Verde. Rates of reactions: OH - Atkinson et al., 2004; IO Dillon et al., 2006; BrO - Sander et al., 2006.

\begin{tabular}{lll}
\hline Radical & $\begin{array}{l}\text { Average mixing ratio } \\
\left(\mathrm{pmol} \mathrm{mol}^{-1}\right)\end{array}$ & $\begin{array}{l}\text { DMS oxidation rate } \\
\left(10^{-6} \mathrm{~s}^{-1}\right)\end{array}$ \\
\hline $\mathrm{OH}$ & 0.25 & 26.4 \\
$\mathrm{BrO}$ & 2.8 & 18.4 \\
$\mathrm{IO}$ & 1.5 & 0.74 \\
\hline
\end{tabular}

$\mathrm{I}_{2} \mathrm{O}_{3}$ and $\mathrm{I}_{2} \mathrm{O}_{4}$, which are produced from the recombination of IO and OIO or the self-association of OIO, respectively (J. C. Gómez Martin, University of Leeds, personal communication, 2009). Quantum calculations, using the same basis set for atomic I described in Kaltsoyannis and Plane (2008), show that $\mathrm{I}_{2} \mathrm{O}_{3}$ does not dimerize effectively with itself, but forms a much more stable complex with $\mathrm{I}_{2} \mathrm{O}_{4} \cdot \mathrm{I}_{2} \mathrm{O}_{4}$ also forms a stable dimer with itself. Hence, $\mathrm{I}_{2} \mathrm{O}_{4}$ appears to be the key species for initiating the formation of IOPs in the MBL. In THAMO, $\mathrm{I}_{2} \mathrm{O}_{4}$ is treated as the primary polymerising species, on which $\mathrm{I}_{2} \mathrm{O}_{3}$ can condense. Both species can condense on larger polymers, which can all also coagulate with each other. These reactions are assumed to occur at their respective collision frequencies (or kernels), which is necessary to model the explosive growth of IOPs observed in the laboratory (Saunders and Plane, 2006).

The total number of particles growing to diameter $=2 \mathrm{~nm}$ are calculated using a semi-implicit, volume conserving coagulation routine as described by Jacobson (2005). Along with growth due to coagulation, $\mathrm{I}_{2} \mathrm{O}_{3}, \mathrm{I}_{2} \mathrm{O}_{4}$ and IOPs are also lost to background aerosols, the rate of which is calculated according to the molecular transfer approximation (Fuchs, 1964). The THAMO model predicts that $\mathrm{I}_{2} \mathrm{O}_{4}$ formation is important only during the night at the IO mixing ratios observed at Cape Verde. This is because $\mathrm{I}_{2} \mathrm{O}_{4}$ forms from the dimerisation of OIO, and OIO photolyzes very rapidly as can be seen in Fig. 4 (Gómez Martin et al., 2009). In the MBL, IOPs can potentially grow much faster due to the uptake of acids and water vapour and there is no reason to expect that condensable vapours in the MBL would not condense onto freshly nucleated particles. Sulphuric acid mixing ratios in the remote MBL range between 0.01-0.03 $\mathrm{pmol} \mathrm{mol}^{-1}$ (e.g. Berresheim et al., 1993), and in the presence of sufficient ammonia $\left(\mathrm{NH}_{3}\right)$, will condense onto any particles that are formed. Indeed recent laboratory experiments at the University of Leeds show that $\mathrm{H}_{2} \mathrm{SO}_{4}$ is taken up on humidified IOPs with a mass accommodation coefficient of 0.75 at $90 \%$ relative humidity (Saunders et al., 2009). The uptake of $\mathrm{H}_{2} \mathrm{SO}_{4}$ on ultrafine particles occurs once the particles are large enough to become "activated"; past studies on other atmospheric particles have shown that the activation size ranges between 1.5 and $3 \mathrm{~m}$ (Kulmala et 
al., 2007). For simplicity, we do not consider a diurnal profile in the $\left[\mathrm{H}_{2} \mathrm{SO}_{4}\right]$ and assume that uptake of ammonia $\left(\mathrm{NH}_{3}\right)$ will keep the $\mathrm{pH}$ of the IOPs close to neutral, so that further uptake of $\mathrm{H}_{2} \mathrm{SO}_{4}$ is not inhibited. This assumption is valid as the background $\mathrm{NH}_{3}$ mixing ratio in the MBL ranges between 25 and $75 \mathrm{pmol} \mathrm{mol}^{-1}$ (Quinn et al., 1988), and aliphatic amines have been observed in sub- $\mu \mathrm{m}$ particles around Cape Verde (Müller et al., 2009).

Results from the THAMO runs using this IOP formation and growth mechanism are illustrated in Fig. 7. The figure shows the number of particles at the measurement height of $10 \mathrm{~m}$, which might grow large enough (taken to be $>20 \mathrm{~nm}$ ) to have a good chance of surviving to become $\mathrm{CCN}$. These are the number of potential CCN formed at $10 \mathrm{~m}$ after $24 \mathrm{~h}$, as a function of the mean daytime $\mathrm{IO}$ concentration at $10 \mathrm{~m}$. The IO is changed by altering the sea-to-air flux of $I_{2}$ species in addition to the halocarbon flux as mentioned in Sect. 4.2. Two cases are illustrated in the figure to show the sensitivity to the background aerosol surface area (ASA), which is set to a typical remote MBL value of $1 \times 10^{-6} \mathrm{~cm}^{2} \mathrm{~cm}^{-3}$ or an ultra-clean value of $1 \times 10^{-7} \mathrm{~cm}^{2} \mathrm{~cm}^{-3}$.

The figure shows that the predicted number of particles is highly sensitive to (i) the background ASA, because the loss to background aerosols through uptake is usually faster than growth by coagulation and condensation (except at high [IO]); and (ii) the IO concentration because the rates of formation of OIO and $\mathrm{I}_{2} \mathrm{O}_{4}$ depend nonlinearly on [IO]. The figure also demonstrates the probability of forming potential $\mathrm{CCN}$ at Cape Verde is vanishingly small. The model predicts a maximum of only $\sim 1 \times 10^{-25}$ particles $\mathrm{cm}^{-3}$ (diameter $=20 \mathrm{~nm}$ ) at the height of measurements when the ASA is $1 \times 10^{-6} \mathrm{~cm}^{2} \mathrm{~cm}^{-3}$, and $\sim 1 \times 10^{-17}$ when the ASA is $2 \times 10^{-7} \mathrm{~cm}^{2} \mathrm{~cm}^{-3}$. Thus, at the mixing ratios of IO seen at Cape Verde, the formation of CCN from iodine chemistry is extremely unlikely. However, the model results show that for a higher [IO], formation of IOPs could be an important source of new particles in the MBL. Such bursts of new particles (diameter $=3-10 \mathrm{~nm}$ ) have been observed in coastal areas peaking at around $2.5 \times 10^{5}$ particles $\mathrm{cm}^{-3}$ (e.g. Whitehead et al., 2009). In these regions [IO] can reach values as high as $\sim 27 \mathrm{pmol} \mathrm{mol}^{-1}$ (e.g. Whalley et al., 2007). Similar bursts have also been observed in Antarctica, where $>4000$ particles $\mathrm{cm}^{-3}$ were observed in the summer (Davison et al., 1996), when the [IO] peaks about $10 \mathrm{pmol} \mathrm{mol}^{-1}$ (Saiz-Lopez et al., 2007). It should be noted that at the levels of IO observed in Cape Verde, there is little change due to the inclusion of particle formation on the predicted IO mixing ratios because most of the higher oxides are lost via uptake on background aerosol. At higher levels of IO, there would be a significant difference to the flux of iodine necessary to sustain IO, if particle formation is switched off (although this depends on whether the higher oxides undergo reasonably rapid photolysis, as proposed by Saiz-Lopez et al. 2008).

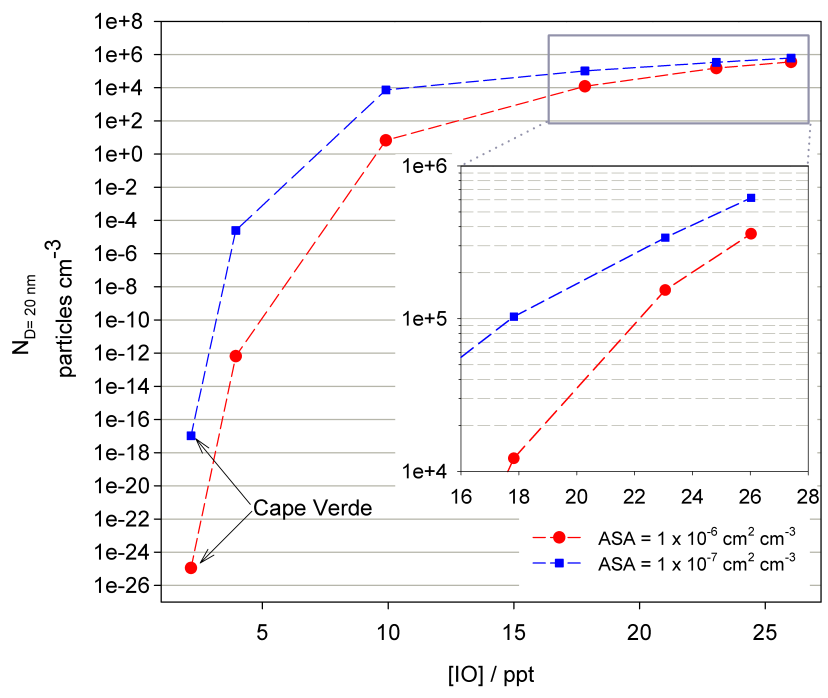

Fig. 7. The number of potential $\mathrm{CCN}$ formed at $10 \mathrm{~m}$ after $24 \mathrm{~h}$, as a function of the mean daytime IO mixing ratio at $10 \mathrm{~m}$. The [IO] is changed by altering the sea-to-air flux of $\mathrm{I}_{2}$ species in addition to the halocarbon flux as mentioned in Sect. 4.2. Two cases are illustrated in the figure to show the sensitivity to the background aerosol surface area (ASA), which is set to a typical remote MBL value of $1 \times 10^{-6} \mathrm{~cm}^{2} \mathrm{~cm}^{-3}$ (red) or an ultra-clean value of $1 \times 10^{-7} \mathrm{~cm}^{2} \mathrm{~cm}^{-3}$ (blue).

\section{Summary and conclusions}

Measurements of halogen species at an open ocean site in the tropical Atlantic Ocean are presented. IO and $\mathrm{BrO}$ are ubiquitously detected at Cape Verde in the presence of sunlight with no apparent dependence on wind speed or direction. Both radicals display a distinct top-hat profile with the maximum values seen between 09:00-07:00 GMT and the annual profile of both species shows little variation. The presence of $\mathrm{IO}$ and $\mathrm{BrO}$ above the detection limit of the DOAS instrument indicates that halogen chemistry could play a wide role in the open ocean MBL. Using the 1-D model THAMO, it is shown that the observed iodocarbon fluxes cannot explain the IO measurements, suggesting that other iodine compounds must be emitted from the ocean surface. The modelling results also show that the observed $\mathrm{O}_{3}$ depletion cannot be explained in the absence of halogen chemistry. The model is able to account for the low $\mathrm{HO}_{\mathrm{x}}$ ratio measured at Cape Verde, indicating that halogen chemistry directly affects the oxidising capacity of the atmosphere. Bromine chemistry is shown to oxidise DMS at rates comparable to $\mathrm{OH}$ affecting the CCN formation potential of DMS. Finally, modelling results suggest that IOP formation does not occur at Cape Verde and higher IO concentrations are necessary to produce particles of a climatically important size. However, further studies are necessary in order to fully understand the potential of iodine chemistry to form $\mathrm{CCN}$ in other open ocean environments. 
Acknowledgements. The authors would like to thank J. C. Gómez Martin and R. Kumar (University of Leeds) for helpful discussion on iodine-particle chemistry. We thank UK Natural Environment Research Council for financial support (NE/D006554/1 - UK NERC Surface Ocean Lower Atmosphere Study and NE/E005659/1). ASM thanks the School of Chemistry, University of Leeds, for a PhD studentship.

Edited by: R. von Glasow

\section{References}

Abbatt, J. P. D. and Nowak, J. B.: Heterogeneous interactions of $\mathrm{HBr}$ and $\mathrm{HOCl}$ with cold sulfuric acid solutions: Implications for arctic boundary layer bromine chemistry, J. Phys. Chem. A, 101, 2131-2137, 1997.

Abbatt, J. P. D. and Waschewsky, G. C. G.: Heterogeneous interactions of $\mathrm{HOBr}, \mathrm{HNO}_{3}, \mathrm{O}_{3}$ and $\mathrm{NO}_{2}$ with deliquescent $\mathrm{NaCl}$ aerosols at room temperature, J. Phys. Chem. A, 102, 37193725, 1998.

Alicke, B., Hebestreit, K., Stutz, J., and Platt, U.: Iodine oxide in the marine boundary layer, Nature, 397, 572-573, 1999.

Allan, B. J., McFiggans, G., Plane, J. M. C., Coe, H., and McFadyen, G. G.: The nitrate radical in the remote marine boundary layer, J. Geophys. Res., 105, 24191-24204, 2000.

Allan, B. J., Plane, J. M. C., and McFiggans, G.: Observations of OIO in the remote marine boundary layer, Geophys. Res. Lett., 28, 1945-1948, 2001.

Allan, J. D., Topping, D. O., Good, N., Irwin, M., Flynn, M., Williams, P. I., Coe, H., Baker, A. R., Martino, M., Niedermeier, N., Wiedensohler, A., Lehmann, S., Mller, K., Herrmann, H., and McFiggans, G.: Composition and properties of atmospheric particles in the eastern Atlantic and impacts on gas phase uptake rates, Atmos. Chem. Phys., 9, 9299-9314, doi:10.5194/acp-99299-2009, 2009.

Andreae, M. O., Atlas, E., Harris, G. W., Helas, G., deKock, A., Koppmann, R., Maenhaut, W., Mano, S., Pollock, W. H., Rudolph, J., Scharffe, D., Schebeske, G., and Welling, M.: Methyl halide emissions from savanna fires in southern Africa, J. Geophys. Res., 101, 23603-23613, 1996.

Atkinson, R., Baulch, D. L., Cox, R. A., Crowley, J. N., Hampson, R. F., Hynes, R. G., Jenkin, M. E., Rossi, M. J., and Troe, J.: Evaluated kinetic and photochemical data for atmospheric chemistry: Volume $\mathrm{I}-$ gas phase reactions of $\mathrm{O}_{\mathrm{x}}, \mathrm{HO}_{x}, \mathrm{NO}_{x}$ and $\mathrm{SO}_{x}$ species, Atmos. Chem. Phys., 4, 1461-1738, doi:10.5194/acp-41461-2004, 2004.

Barrie, L. A., Bottenheim, J. W., Schnell, R. C., Crutzen, P. J., and Rasmussen, R. A.: Ozone destruction and photochemicalreactions at polar sunrise in the lower arctic atmosphere, Nature, 334, 138-141, 1988.

Behnke, W., Scheer, V., and Zetzsch, C.: Production of $\mathrm{BrNO}_{2}$, $\mathrm{Br}$ and $\mathrm{ClNO}_{2}$ from the reaction between sea spray aerosol and $\mathrm{N}_{2} \mathrm{O}_{5}$, J. Aero. Sci., 25, S277-S278, 1994.

Berresheim, H., Eisele, F. L., Tanner, D. J., McInnes, L. M., Ramsey-Bell, D. C., and Covert, D. S.: Atmospheric sulphur chemistry and cloud condensation nuclei $(\mathrm{CCN})$ concentrations over the northeastern pacific coast, J. Geophys. Res., 98(D7), 12701-12711, 1993.
Bloss, W. J., Lee, J. D., Johnson, G. P., Sommariva, R., Heard, D. E., Saiz-Lopez, A., Plane, J. M. C., McFiggans, G., Coe, H., Flynn, M., Williams, P., Rickard, A. R., and Fleming, Z. L.: Impact of halogen monoxide chemistry upon boundary layer $\mathrm{OH}$ and $\mathrm{HO}_{2}$ concentrations at a coastal site, Geophys. Res. Lett., 32, L06814, 10.1029/2004GL022084, 2005.

Bobrowski, N., Hönninger, G., Galle, B., and Platt, U.: Detection of bromine monoxide in a volcanic plume, Nature, 423, 273-276, 2003.

Bongartz, A., Kames, J., Welter, F., and Schurath, U.: Near-UV absorption cross-sections and trans cis equilibrium of nitrous-acid, J. Phys. Chem., 95, 1076-1082, 1991.

Bottenheim, J. W., Gallant, A. G., and Brice, K. A.: Measurements of $\mathrm{NO}_{y}$ Species and $\mathrm{O}_{3}$ at 82-Degrees-N Latitude, Geophys. Res. Lett., 13, 113-116, 1986.

Brooks, S. B., Saiz-Lopez, A., Skov, H., Lindberg, S. E., Plane, J. M. C., and Goodsite, M. E.: The mass balance of mercury in the springtime arctic environment, Geophys. Res. Lett., 33, L13812, doi:10.1029/2005GL025525, 2006.

Burkholder, J. B., Curtius, J., Ravishankara, A. R., and Lovejoy, E. R.: Laboratory studies of the homogeneous nucleation of iodine oxides, Atmos. Chem. Phys., 4, 19-34, doi:10.5194/acp-4-192004, 2004.

Cantrell, C. A., Davidson, J. A., McDaniel, A. H., Shetter, R. E., and Calvert, J. G.: Temperature-dependent formaldehyde crosssections in the near-ultraviolet spectral region, J. Phys. Chem., 94, 3902-3908, 1990.

Carpenter, L. J., Sturges, W. T., Penkett, S. A., Liss, P. S., Alicke, B., Hebestreit, K., and Platt, U.: Short-lived alkyl iodides and bromides at Mace Head, Ireland: Links to biogenic sources and halogen oxide production, J. Geophys. Res., 104, 1679-1689, 1999.

Chang, W., Heikes, B. G., and Lee, M.: Ozone deposition to the sea surface: chemical enhancement and wind speed dependence, Atmos. Env., 38, 1053-1059, 2004.

Daumont, D., Brion, J., Charbonnier, J., and Malicet, J.: Ozone UV Spectroscopy. 1. Absorption cross-sections at room temperature, J. Atmos. Chem., 15, 145-155, 1992.

Davison, B., Hewitt, C. N., O’Dowd, C. D., Lowe, J. A., Smith, M. H., Schwikowski, M., Baltensperger, U. and Harrison, R. M.: Dimethyl sulphide, methane sulphonic acid and physiochemical aerosol properties in Atlantic air from the United Kingdom to Halley Bay, J. Geophys. Res., 101(D17), 22855-22867, 1996.

Dillon, T. J., Karunanandan, R., and Crowley, J. N.: The reaction of $\mathrm{IO}$ with $\mathrm{CH}_{3} \mathrm{SCH}_{3}$ : products and temperature dependent rate coefficients by laser induced fluorescence, Phys. Chem. Chem. Phys., 8, 847-855, 2006.

Fallowski, P. G.: Evolution of the nitrogen cycle and its influence on the biological sequestration of $\mathrm{CO}_{2}$ in the ocean, Nature, 387, 272-275, 1997.

Fickert, S., Adams, J. W., and Crowley, J. N.: Activation of $\mathrm{Br}_{2}$ and $\mathrm{BrCl}$ via uptake of $\mathrm{HOBr}$ onto aqueous salt solutions, J. Geophys. Res., 104, 23719-23727, 1999.

Finley, B. D. and Saltzman, E. S.: Observations of $\mathrm{Cl}_{2}, \mathrm{Br}_{2}$, and $\mathrm{I}_{2}$ in coastal marine air, J. Geophys. Res., 113, D21301, doi:10.1029/2008JD010269, 2008.

Frieß, U., Wagner, T., Pundt, I., Pfeilsticker, K., and Platt, U.: Spectroscopic measurements of tropospheric iodine oxide at Neumayer Station, Antarctica, Geophys. Res. Lett., 28, 1941-1944, 
2001.

Frieß, U., Hollwedel, J., Konig-Langlo, G., Wagner, T., and Platt, U.: Dynamics and chemistry of tropospheric bromine explosion events in the Antarctic coastal region, J. Geophys. Res.-Atmos., 109, D06305, doi:10.1029/2003JD004133, 2004.

Fuchs, N. A.: The mechanics of aerosols, Pergamon Press, New York, 1964.

Gabriel, R., von Glasow, R., Sander, R., Andreae, M., and Crutzen, P. J.: Bromide content of sea-salt aerosol particles collected over the Indian Ocean during INDOEX 1999, J. Geophys. Res., 107(D19), 8032, doi:10.1029/2001JD001133, 2002.

Garland, J. A., Elzerman, A. W., and Penket, S. A.: The mechanism for dry deposition of ozone to seawater surfaces, J. Geophys. Res., 85, 7488-7492, 1980.

Garland, J. A. and Curtis, H.: Emisson of iodine from the seasurface in the presence of ozone, J. Geophys. Res., 86, 31833186, 1981.

Gebhardt, S., Colomb, A., Hofmann, R., Williams, J., and Lelieveld, J.: Halogenated organic species over the tropical South American rainforest, Atmos. Chem. Phys., 8, 3185-3197, doi:10.5194/acp-8-3185-2008, 2008.

Gilles, M. K., Turnipseed, A. A., Burkholder, J. B., Ravishankara, A. R., and Solomon, S. J.: Kinetics of the IO radical. 2. Reaction of IO with BrO, J. Phys. Chem. A, 101, 30, 5526-5534, 1997.

Gómez Martin, J. C., Ashworth, S. H., Mahajan, A. S., and Plane, J. M. C.: Photochemistry of OIO: Laboratory study and atmospheric implications, Geophys. Res. Lett., 36, L09802, doi:10.1029/2009GL037642, 2009.

Gómez Martin, J. C., Spietz, P., and Burrows, J. P.: Spectroscopic studies of the $\mathrm{I}_{2} / \mathrm{O}_{3}$ photochemistry - Part 1: Determination of the absolute absorption cross sections of iodine oxides of atmospheric relevance, J. Photochem. Photobio. A-Chem., 176, 1538, 2005.

Harder, J. W., Brault, J. W., Johnston, P. V., and Mount, G. H.: Temperature dependent $\mathrm{NO}_{2}$ cross sections at high spectral resolution, J. Geophys. Res., 102, 3861-3879, 1997.

Hausmann, M. and Platt, U.: Spectroscopic measurement of bromine oxide and ozone in the high arctic during polar sunrise experiment 1992, J. Geophys. Res., 99, 25399-25413, 1994.

Hebestreit, K., Stutz, J., Rosen, D., Matveiv, V., Peleg, M., Luria, M., and Platt, U.: DOAS measurements of tropospheric bromine oxide in mid-latitudes, Science, 283, 55-57, 1999.

Hoffmann, T., O'Dowd, C. D., and Seinfeld, J. H.: Iodine oxide homogeneous nucleation: An explanation for coastal new particle production, Geophys. Res. Lett., 28, 1949-1952, 2001.

Hönninger, G.: Halogen Oxide Studies in the Boundary Layer by Multi Axis Differential Optical Absorption Spectroscopy and Active Longpath-DOAS, PhD Thesis, University of Heidelberg, Germany, 2002.

Hönninger, G., Leser, H., Sebastian, O., and Platt, U.: Groundbased measurements of halogen oxides at the Hudson Bay by active longpath DOAS and passive MAX-DOAS, Geophys. Res. Lett., 31, L04111, doi:10.1029/2003GL018982, 2004.

Jacobson, M. Z.: Fundamentals of atmospheric modelling, Cambridge University Press, Cambridge, 2005.

Jimenez, J. L., Bahreini, R., D. R. C., Zhuang, H., Varutbangkul, V., Flagan, R. C., Seinfeld, J. H., O’Dowd, C. D., and Hoffmann, T.: New particle formation from photooxidation of diiodomethane $\left(\mathrm{CH}_{2} \mathrm{I}_{2}\right)$, J. Geophys. Res., D10, 4318,
doi:10.1029/2002JD002452, 2003

Jones, A. E., Anderson, P. S., Wolff, E. W., Turner, J., Rankin, A. M., and Colwell, S. R.: A role for newly forming sea ice in springtime polar tropospheric ozone loss? Observational evidence from Halley station, Antarctica, J. Geophys. Res., 111, D08306, doi:10.1029/2005JD006566, 2006.

Jones, C. E., Hornsby, K. E., Sommirava, R., Dunk, R. M., von Glasow, R., McFiggans, G. B., and Carpenter, L. J.: Quantifying the sources and atmospheric impact of marine organic iodine gases, in preparation, 2010.

Kaltsoyannis, N. and Plane, J. M. C.: Quantum chemical calculations on a selection of iodine-containing species (IO, OIO, $\mathrm{INO}_{3}$, $(\mathrm{IO})_{2}, \mathrm{I}_{2} \mathrm{O}_{3}, \mathrm{I}_{2} \mathrm{O}_{4}$ and $\mathrm{I}_{2} \mathrm{O}_{5}$ of importance in the atmosphere, Phys. Chem. Chem. Phys, 10, 1723-1733, 2008.

Kreher, K., Johnston, P. V., Wood, S. W., Nardi, B., and Platt, U.: Ground-based measurements of tropospheric and stratospheric $\mathrm{BrO}$ at Arrival Heights, Antarctica, Geophys. Res. Lett., 24, 3021-3024, 1997.

Kulmala, M., Piipinen, I., Silila, M., Manninen, H. E., Petaja, T., Junninen, H., Dal Maso, M., Mordas, G., Mirme, A., Vana, M., Hirsikko, A., Laakso, L., Harrison, R. M., Hanson, I., Leung, C., Lehtinen, K. E. J., and Kerminen, V.-M.: Toward direct measurement of atmospheric nucleation, Science, 318, 89-92, 2007

Lee, C., Kim, Y. J., Tanimoto, H., Bobrowski, N., Platt, U., Mori, T., Yamamoto, K., and Hong, C. S.: High $\mathrm{ClO}$ and ozone depletion observed in the plume of Sakurajima volcano, Japan, Geophys. Res. Lett., 32, L21809, doi:10.1029/2005GL023785, 2005.

Lee, J. D., McFiggans, G., Allan, J. D., Baker, A. R., Ball, S. M., Benton, A. K., Carpenter, L. J., Commane, R., Finley, B. D., Evans, M., Fuentes, E., Furneaux, K., Goddard, A., Good, N., Hamilton, J. F., Heard, D. E., Herrmann, H., Hollingsworth, A., Hopkins, J. R., Ingham, T., Irwin, M., Jones, C. E., Jones, R. L., Keene, W. C., Lawler, M. J., Lehmann, S., Lewis, A. C., Long, M. S., Mahajan, A., Methven, J., Moller, S. J., Mller, K., Mller, T., Niedermeier, N., O’Doherty, S., Oetjen, H., Plane, J. M. C., Pszenny, A. A. P., Read, K. A., Saiz-Lopez, A., Saltzman, E. S., Sander, R., von Glasow, R., Whalley, L., Wiedensohler, A., and Young, D.: Reactive Halogens in the Marine Boundary Layer (RHaMBLe): the tropical North Atlantic experiments, Atmos. Chem. Phys., 10, 1031-1055, doi:10.5194/acp-10-10312010, 2010.

Leser, H., Hönninger, G., and Platt, U.: MAX-DOAS measurements of $\mathrm{BrO}$ and $\mathrm{NO}_{2}$ in the marine boundary layer, Geophys. Res. Lett., 30, 10, 1537, doi:10.1029/2002GL015811, 2003.

Mahajan, A. S., Shaw, M., Oetjen, H., Hornsby, K., Carpenter, L. J., Kaleschke, L., Tian-Kunze, X., Lee, J. D., Moller, S. J., Edwards, P., Commane, R., Ingham, T., Heard, D.E., and Plane, J. M. C.: Evidence of reactive iodine chemistry in the Arctic boundary layer, J. Geophys. Res., submitted, 2009a.

Mahajan, A. S., Oetjen, H., Lee, J. D., Saiz-Lopez, A., McFiggans, G. B., and Plane, J. M. C.: High bromine oxide concentrations in the semi-polluted boundary layer, Atmos. Env., 43, 3811-3818, doi:10.1016/j.atmosenv.2009.05.033, 2009b.

Mahajan, A. S., Oetjen, H., Saiz-Lopez, A., Lee, J. D., McFiggans, G. B., and Plane, J. M. C.: Reactive iodine species in a semi-polluted environment, Geophys. Res. Lett., 36, L16803, doi:10.1029/2009GL038018, 2009c.

Mäkelä, J. M., Hoffmann, T., Holzke, C., Vakeva, M., Suni, T., Mattila, T., Aalto, P. P., Tapper, U., Kauppinen, E. I., and O’Dowd, C. 
D.: Biogenic iodine emissions and identification of end-products in coastal ultrafine particles during nucleation bursts, J. Geophys. Res., 107(D19), 8110, doi:10.1029/2001JD000580, 2002.

Martin, M., Pöhler, D., Seitz, K., Sinreich, R., and Platt, U.: BrO measurements over the Eastern North-Atlantic, Atmos. Chem. Phys., 9, 9545-9554, doi:10.5194/acp-9-9545-2009, 2009.

Martino, M., Mills, G. P., Woetjen, J., and Liss, P. S.: A new source of volatile organoiodine compounds in surface seawater, Geophys. Res. Lett., 36, L01609, doi:10.1029/2008GL036334, 2009.

McFiggans, G., Coe, H., Burgess, R., Allan, J., Cubison, M., Alfarra, M. R., Saunders, R., Saiz-Lopez, A., Plane, J. M. C., Wevill, D., Carpenter, L., Rickard, A. R., and Monks, P. S.: Direct evidence for coastal iodine particles from Laminaria macroalgae - linkage to emissions of molecular iodine, Atmos. Chem. Phys., 4, 701-713, doi:10.5194/acp-4-701-2004, 2004.

Mochida, M., Hirokawa, J., and Akimoto, H.: Unexpected large uptake of $\mathrm{O}_{3}$ on sea-salts and the observed $\mathrm{Br}-2$ formation, Geophys. Res. Lett., 27, 2629-2632, 2000.

Molina, M. J. and Rowland, F. S.: Stratospheric Sink for Chlorofluoromethanes - Chlorine Atomic-Catalysed Destruction of Ozone, Nature, 249, 810-812, 1974.

Mozurkewich, M.: Mechanisms for the release of halogens from sea-salt particles by free radical reactions, J. Geophys. Res., 100, 14199-14207, 1995.

Müller, C., Iinuma, Y., Karstensen, J., van Pinxteren, D., Lehmann, S., Gnauk, T., and Herrmann, H.: Seasonal variation of aliphatic amines in marine sub-micrometer particles at the Cape Verde islands, Atmos. Chem. Phys., 9, 9587-9597, doi:10.5194/acp-99587-2009, 2009.

Newberg, J. T., Matthew, B. M., and Anastasio, C.: Chloride and bromide depletions in sea-salt particles over the northeastern Pacific Ocean, J. Geophys. Res., 110, D06209, doi:10.1029/2004JD005446, 2005.

O'Dowd, C. D., Geever, M., and Hill, M. K.: New particle formation: Nucleation rates and spatial scales in the clean marine coastal environment, Geophys. Res. Lett., 25, 1661-1664, 1998.

Perner, D. and Platt, U.: Detection of nitrous-acid in the atmosphere by differential optical absorption, Geophys. Res. Lett., 6, $917-$ 920, 1979.

Peters, C., Pechtl, S., Stutz, J., Hebestreit, K., Hönninger, G., Heumann, K. G., Schwarz, A., Winterlik, J., and Platt, U.: Reactive and organic halogen species in three different European coastal environments, Atmos. Chem. Phys., 5, 3357-3375, doi:10.5194/acp-5-3357-2005, 2005.

Plane, J. M. C. and Saiz-Lopez, A.: UV-Visible Differential Optical Absorption Spectroscopy (DOAS) in: Analytical Techniques for Atmospheric Measurement, Blackwell, Oxford, 2006.

Platt, U., Perner, D., and Pätz, H. W.: Simultaneous measurement of Atmospheric $\mathrm{CH}_{2} \mathrm{O}, \mathrm{O}_{3}$ and $\mathrm{NO}_{2}$ by differential optical absorption, J. Geophys. Res., 84, 6329-6335, 1979.

Quinn, P. K., Charlson, R. J., and Bates, T. S.: Simultaneous measurements of ammonia in the atmosphere and ocean, Nature, 335, 336-338, doi:10.1038/335336a0, 1988.

Read, K. A., Mahajan, A. S., Carpenter, L. J., Evans, M. J., Faria, B. V. E., Heard, D. E., Hopkins, J. R., Lee, J. D., Moller, S. J., Lewis, A. C., Mendes, L., McQuaid, J. B., Oetjen, H., SaizLopez, A., Pilling, M. J., and Plane, J. M. C.: Extensive halogenmediated ozone destruction over the tropical Atlantic Ocean, Nature, 453, 7199, 1232-1235, 2008.
Read, K. A., Lee, J. D., Lewis, A. C., Moller, S. J., Neves, L. M., and Carpenter, L. J.: Intra-annual cycles of NMVOC in the tropical marine boundary layer and their use for interpreting seasonal variability in CO, J. Geophys. Res.-Atmos., 114, D21303, doi:10.1029/2009JD011879, 2009.

Reeser, D. I., Jammoul, A., Clifford, D., Brigante, M., D’Anna, B., George, C., and Donaldson, D. J.: Photoenhanced reaction of ozone with chlorophyll at the seawater surface, J. Pys. Chem. C, 113(6), 2071-2077, 2009.

Richter, A., Wittrock, F., Eisinger, M., and Burrows, J. P.: GOME observations of tropospheric BrO in northern hemispheric spring and summer 1997, Geophys. Res. Lett., 25, 2683-2686, 1998.

Rothman, L. S., Barbe, A., Benner, D. C., Brown, L. R., CamyPeyret, C., Carleer, M. R., Chance, K., Clerbaux, C., Dana, V., Devi, V. M., Fayt, A., Flaud, J. M., Gamache, R. R., Goldman, A., Jacquemart, D., Jucks, K. W., Lafferty, W. J., Mandin, J. Y., Massie, S. T., Nemtchinov, V., Newnham, D. A., Perrin, A., Rinsland, C. P., Schroeder, J., Smith, K. M., Smith, M. A. H., Tang, K., Toth, R. A., Vander Auwera, J., Varanasi, P., and Yoshino, K.: The HITRAN molecular spectroscopic database: edition of 2000 including updates through 2001, J. Quant. Spectros. Radia. Transfer, 82, 5-44, 2003.

Saiz-Lopez, A., Plane, J. M. C., and Shillito, J. A.: Bromine oxide in the mid-latitude marine boundary layer, Geophys. Res. Lett., 31, L03111, doi:10.1029/2003GL018956, 2004.

Saiz-Lopez, A. and Plane, J. M. C.: Novel iodine chemistry in the marine boundary layer, Geophys. Res. Lett., 31, L04112, doi:10.1029/2003GL019215, 2004.

Saiz-Lopez, A., Mahajan, A. S., Salmon, R. A., Bauguitte, S. J. B., Jones, A. E., Roscoe, H. K., and Plane, J. M. C.: Boundary layer halogens in coastal Antarctica, Science, 317, 348-351, 2007a.

Saiz-Lopez, A., Chance, K., Liu, X., Kurosu, T. P., and Sander, S. P.: First observations of iodine oxide from space, Geophys. Res. Lett., 34, L12812, doi:10.1029/2007GL030111, 2007b.

Saiz-Lopez, A., Plane, J. M. C., Mahajan, A. S., Anderson, P. S., Bauguitte, S. J.-B., Jones, A. E., Roscoe, H. K., Salmon, R. A., Bloss, W. J., Lee, J. D., and Heard, D. E.: On the vertical distribution of boundary layer halogens over coastal Antarctica: implications for $\mathrm{O}_{3}, \mathrm{HO}_{\mathrm{x}}, \mathrm{NO}_{\mathrm{x}}$ and the $\mathrm{Hg}$ lifetime, Atmos. Chem. Phys., 8, 887-900, doi:10.5194/acp-8-887-2008, 2008.

Sakamoto, Y., Yabushita, A., Kawasaki, M., and Enami, S.: Direct Emission of $\mathrm{I}_{2}$ Molecule and IO Radical from the Heterogeneous Reactions of Gaseous Ozone with Aqueous Potassium Iodide Solution, The J. Phys. Chem. A, 113, 7707-7713, 2009.

Sander, R. and Crutzen, P. J.: Model study indicating halogen activation and ozone depletion in the polluted air masses transported to the sea, J. Geophys. Res., 101(D4), 9121-9138, 1996.

Sander, R., Keene, W. C., Pszenny, A. A. P., Arimoto, R., Ayers, G. P., Baboukas, E., Cainey, J. M., Crutzen, P. J., Duce, R. A., Hnninger, G., Huebert, B. J., Maenhaut, W., Mihalopoulos, N., Turekian, V. C., and Van Dingenen, R.: Inorganic bromine in the marine boundary layer: a critical review, Atmos. Chem. Phys., 3, 1301-1336, doi:10.5194/acp-3-1301-2003, 2003.

Sander, S. P., Orkin, V. L., Kurylo, M. J., Golden, D. M., Huie, R. E., Kolb, C. E., Finlayson-Pitts, B. J., Molina, M. J., Friedl, R. R., Ravishankara, A. R., Moortgat, G. K., Keller-Rudek, H., and Wine, P. H.: Chemical kinetics and photochemical data for use in atmospheric studies, Technical report, NASA-JPL, 2006. 
Saunders, R. W. and Plane, J. M. C.: Formation pathways and composition of iodine oxide ultra-fine particles, Env. Chem., 2, 299303, 2005.

Saunders, R. W. and Plane, J. M. C.: Fractal growth modelling of $\mathrm{I}_{2} \mathrm{O}_{5}$ nanoparticles, J. Aero. Sci., 37(12), 1737-1749, 2006.

Saunders, R.W., Kumar, R., Gómez Martin, J. C., Mahajan, A. S., Murray, B. J., and Plane, J. M. C.: Studies of the formation and growth of aerosol from molecular iodine precursor, Z. Phys. Chem., submitted, 2009.

Schroeder, W., Anlauf, K., Barrie, L., Lu, J., Steffen, A., Schneeberger, D., and Berg, T.: Arctic springtime depletion of mercury, Nature, 394, 331-332, 1998.

Schönhardt, A., Richter, A., Wittrock, F., Kirk, H., Oetjen, H., Roscoe, H. K., and Burrows, J. P.: Observations of iodine monoxide columns from satellite, Atmos. Chem. Phys., 8, 637653, doi:10.5194/acp-8-637-2008, 2008.

Sommariva, R., Bloss, W. J., Brough, N., Carslaw, N., Flynn, M., Haggerstone, A.-L., Heard, D. E., Hopkins, J. R., Lee, J. D., Lewis, A. C., McFiggans, G., Monks, P. S., Penkett, S. A., Pilling, M. J., Plane, J. M. C., Read, K. A., Saiz-Lopez, A., Rickard, A. R., and Williams, P. I.: $\mathrm{OH}$ and $\mathrm{HO}_{2}$ chemistry during NAMBLEX: roles of oxygenates, halogen oxides and heterogeneous uptake, Atmos. Chem. Phys., 6, 1135-1153, doi:10.5194/acp-6-1135-2006, 2006.

Stolarsky, R. S. and Cicerone, R. J.: Stratospheric Chlorine Possible Sink for Ozone, Can. J. Chem.-Revue Canadienne De Chimie, 52, 1610-1615, 1974.

Stull, R. B.: An introduction to boundary layer meteorology, Kluwer Academic Publishers, London, 1988.

Stutz, J., Ackermann, R., Fast, J. D., and Barrie, L.: Atmospheric reactive chlorine and bromine at the Great Salt Lake, Utah, Geophys. Res. Lett., 29, 1380, doi:10.1029/2002GL014812, 2002.

Stutz, J., Pikelnaya, O., Hurlock, S. C., Trick, S., Pechtl, S., and von Glasow, R.: Daytime OIO in the gulf of Maine, Geophys. Res. Lett., 34, L22816, doi:10.1029/2002GL014812, 2007.

Theiler, R., Cook, J. C., and Hager, L. P.: Halohydrocarbon Synthesis by Bromoperoxidase, Science, 202, 1094-1096, 1978.

Theys, N., Van Roozendael, M., Hendrick, F., Fayt, C., Hermans, C., Baray, J.-L., Goutail, F., Pommereau, J.-P., and De Mazire, M.: Retrieval of stratospheric and tropospheric BrO columns from multi-axis DOAS measurements at Reunion Island $\left(21^{\circ} \mathrm{S}\right.$, $56^{\circ}$ E), Atmos. Chem. Phys., 7, 4733-4749, doi:10.5194/acp-74733-2007, 2007.

Toumi, R.: BrO as a sink for dimethylsulphide in the marine atmosphere, Geophys. Res. Lett., 21, 117-120, 1994.

Tuckermann, M., Ackermann, R., Golz, C., LorenzenSchmidt, H., Senne, T., Stutz, J., Trost, B., Unold, W., and Platt, U.: DOASobservation of halogen radical-catalysed arctic boundary layer ozone destruction during the ARCTOC-campaigns 1995 and 1996 in Ny-Alesund, Spitsbergen, Tellus B-Chem. Phys. Meteo., 49, 533-555, 1997.

Turnipseed, A. A. Barone, S. B., and Ravishankara, A. R.: Reaction of $\mathrm{OH}$ with dimethyl sulphide (DMS) - 2. Products and mechanisms, J. Phys. Chem., 100, 14703-14713, 1996.

Vandaele, A. C., Hermans, C., Simon, P., Carleer, M., Colins, R., Fally, F., Merienne, M. F., Jenouvrier, A., and Coquart, B.: Measurements of $\mathrm{NO}_{2}$ absorption cross-sections at $42000 \mathrm{~cm}^{-1}$ to $10000 \mathrm{~cm}^{-1}(238-1000 \mathrm{~nm})$ at $220 \mathrm{~K}$ and $298 \mathrm{~K}$, J. Quant. Spectros. Radia. Transfer, 59, 171-184, 1998.
Vogt, R., Crutzen, P., and Sander, R.: A mechanism for halogen release from sea-salt aerosol in the remote marine boundary layer, Nature, 383, 327-330, 1996.

von Glasow, R., Sander, R., Bott, A., and Crutzen, P. J.: Modeling halogen chemistry in the marine boundary layer 1. Cloud-free MBL, J. Geophys. Res., 107(D17), 4341, doi:10.1029/2001JD000942, 2002a.

von Glasow, R., Sander, R., Bott, A., and Crutzen, P. J.: Modeling halogen chemistry in the marine boundary layer -2 . Interactions with sulfur and the cloud-covered MBL, J. Geophys. Res., 107(D17), 4323, doi:10.1029/2001JD000943, 2002 b.

von Glasow, R., von Kuhlmann, R., Lawrence, M. G., Platt, U., and Crutzen, P. J.: Impact of reactive bromine chemistry in the troposphere, Atmos. Chem. Phys., 4, 2481-2497, doi:10.5194/acp4-2481-2004, 2004.

von Glasow, R. and Crutzen, P. J.: Model study of multiphase DMS oxidation with a focus on halogens, Atmos. Chem. Phys., 4, 589608, doi:10.5194/acp-4-589-2004, 2004.

von Glasow, R. and Crutzen, P. J.: Tropospheric Halogen Chemistry, in: Treatise on Geochemistry, The Atmosphere, ElsevierPergamon, Oxford, 2007.

Wagner, T. and Platt, U.: Satellite mapping of enhanced BrO concentrations in the troposphere, Nature, 395, 486-490, 1998.

Wennberg, P.: Atmospheric chemistry - Bromine explosion, Nature, 397, 299-301, 1999.

Wessel, S., Aoki, S., Winkler, P., Weller, R., Herber, A., Gernandt, H., and Schrems, O.: Tropospheric ozone depletion in polar regions - A comparison of observations in the Arctic and Antarctic, Tellus B-Chem. Phys. Meteo., 50, 34-50, 1998.

Wever, R., Tromp, M. G. M., Krenn, B. E., Marjani, A., and Vantol, M.: Brominating activity of the seaweed Ascophyllum-nodosum - impact on the biosphere, Env. Sci. Tech., 25, 446-449, 1991.

Whalley, L. K., Furneaux, K. L., Gravestock, T., Atkinson, H. M., Bale, C. S. E., Ingham, T., Bloss, W. J., and Heard, D. E.: Detection of iodine monoxide radicals in the marine boundary layer using laser induced fluorescence spectroscopy, J. Atmos. Chem., 58(1), 19-39, 2007.

Whalley, L. K., Furneaux, K. L., Goddard, A., Lee, J. D., Mahajan, A., Oetjen, H., Read, K. A., Kaaden, N., Carpenter, L. J., Lewis, A. C., Plane, J. M. C., Saltzman, E. S., Wiedensohler, A., and Heard, D. E.: The chemistry of $\mathrm{OH}$ and $\mathrm{HO}_{2}$ radicals in the boundary layer over the tropical Atlantic Ocean, Atmos. Chem. Phys., 10, 1555-1576, doi:10.5194/acp-10-1555-2010, 2010.

Whitehead, J. D., McFiggans, G. B., Gallagher, M. W., and Flynn, M. J.: Direct linkage between tidally driven coastal ozone deposition fluxes, particle emission fluxes, and subsequent CCN formation, Geophys. Res. Lett., 36, L04806, doi:10.1029/2008GL035969, 2009

Wilmouth, D. M., Hanisco, T. F., Donahue, N. M., and Anderson, J. G.: Fourier transform ultraviolet spectroscopy of the A $2 \Pi 3 / 2 \leftarrow X 2 \Pi 3 / 2$ transition of BrO, J. Phys. Chem. A, 103, 8935-8945, 1999.

Wilson, T. R. S.: Salinity and the major elements of sea water: in Chemical Oceanography, editor: Riley, J. P. and Skirrow, G, Second ed., Academic Press, 1975.

Wittrock, F., Müller, R., Richter, A., Bovensmann, H., and Burrows, J. P.: Measurements of Iodine monoxide (IO) above Spitsbergen, Geophys. Res. Lett., 27, 1471-1474, 2000. 
A. S. Mahajan et al.: Measurement and modelling of tropospheric reactive halogen species

Yang, X., Cox, R. A., Warwick, N. J., Pyle, J. A., Carver, G. D., O'Connor, F. M., and Savage, N. H.: Tropospheric bromine chemistry and its impacts on ozone: A model study, J. Geophys. Res., 110, D23311, doi:10.1029/2005JD006244, 2005.
Zingler, J. and Platt, U.: Iodine oxide in the Dead Sea Valley: Evidence for inorganic sources of boundary layer IO, J. Geophys. Res., 110, D07307, doi:10.1029/2004JD004993, 2005. 